NBSIR 79-1737

\title{
Testing of Pebble-Bed and Phase-Change Thermal Energy Storage Devices According to ASHRAE Standard 94-77
}

Dennis E. Jones James E. Hill

Building Thermal and Service Systems Division Center for Building Technology National Engineering Laboratory National Bureau of Standards Washington, D.C. 20234

May 1979

Sponsored by

The Department of Energy 12th and Pennsylvania Ave., NW Washington, D.C. 20461 

1,1

TESTING OF PEBBLE-BED AND

PHASE-CHANGE THERMAL ENERGY

STORAGE DEVICES ACCORDING TO

ASHRAE STANDARD 94-77

Dennis E. Jones

James E. Hill

Building Thermal and Service Systems Division Center for Building Technology

National Engineering Laboratory

National Bureau of Standards

Washington, D.C. 20234

May 1979

Prepared for:

Research and Development Branch for Solar Heating and Cooling Office of Conservation and Solar Applications

Department of Energy

Washington, D.C. 20545

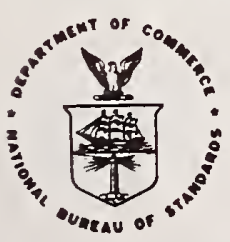

U.S. DEPARTMENT OF COMMERCE, Juanita M. Kreps, Secretary

Jordan J. Baruch, Assistant Secretary for Science and Technology

NATIONAL BUREAU OF STANDARDS, Ernest Ambler, Director 
ABSTRACT $\ldots \ldots \ldots \ldots \ldots \ldots \ldots \ldots \ldots \ldots \ldots \ldots \ldots \ldots \ldots \ldots \ldots \ldots \ldots \ldots \ldots \ldots$

1. INTRODUCTION $\ldots \ldots \ldots \ldots \ldots \ldots \ldots \ldots \ldots \ldots \ldots \ldots \ldots \ldots \ldots \ldots \ldots \ldots \ldots \ldots \ldots$

2. ASHRAE STANDARD $94-77 \ldots \ldots \ldots \ldots \ldots \ldots \ldots \ldots \ldots \ldots \ldots \ldots \ldots \ldots \ldots \ldots \ldots$

3. NBS TEST FACILITY............................ 7

4. EXPERIMENTAL PROCEDURE ............................. 18

5. PHASE-CHANGE DEVICE TEST RESULTS..................... 19

6. PEBBLE-BED TEST RESULTS.......................... 32

7. CONCLUSIONS AND RECOMMENDATIONS .................... 38

8. REFERENCES.................................... 40 


\title{
TESTING OF PEBBLE-BED AND PHASE-CHANGE THERMAL ENERGY STORAGE DEVICES ACCORDING TO ASHRAE STANDARD 94-77
}

by

\author{
Dennis E. Jones \\ James E. Hi 11
}

\section{ABSTRACT}

The American Society of Heating, Refrigerating, and Air Conditioning Engineers (ASHRAE) has recently adopted ASHRAE Standard 94-77 - Methods of Testing Thermal Storage Devices Based on Thermal Performance. Experiments have been completed at the National Bureau of Standards in which a $7 \mathrm{~m}^{3}\left(250 \mathrm{ft}^{3}\right)$ pebble-bed and a similarly-sized $264 \mathrm{MJ}(250,000$ Btu) phase-change unit utilizing sodium sulfate decahydrate, both using air as the transfer fluid, were tested in accordance with this Standard. A description of the test procedure, test apparatus, and detailed test results is given. Some problems were encountered in using the Standard for these kinds of thermal energy storage devices, and modifications to the Standard are recommended based on these experiments.

KEY WORDS: ASHRAE Standard 94-77; Glauber's salt; latent heat storage; pebble-bed; phase-change unit; solar energy storage; thermal storage device. 


\title{
TESTING OF PEBBLE-BED AND PHASE-CHANGE THERMAL STORAGE
}

DEVICES ACCORDING TO ASHRAE STANDARD 94-77

\author{
by \\ Dennis E. Jones \\ James E. Hill
}

\section{INTRODUCTION}

Beginning in early 1974, the staff of the National Bureau of Standards (NBS) began the development of thermal test procedures for the two primary non-conventional components of solar heating and cooling systems-solar coliectors and thermal energy storage devices. Recommended procedures for testing both components were published in late 1974 and early 1975 [1,2] in a format consistent with the standards of the American Society of Heating, Refrigerating, and Air Conditioning Engineers (ASHRAE). The procedures were later published with supplementary information explaining the rationale behind each procedure $[3,4,5]$.

In July of 1975, ASHRAE formed Standards Project Committee 94-P to develop a standard for the testing of thermal energy storage devices. In June, 1976, a draft of a standard was published and submitted to the Society for review. It was based substantially on the previously published NBS recommended procedure [2]. The ASHRAE draft was modified according to the review comments received and then forwarded to the ASHRAE Standards Committee for approval. In February, 1977, the ASHRAE Board of Directors approved and authorized publication of ASHRAE Standard 94-77 - Methods of Testing Thermal Storage Devices Based on Thermal Performance [6].

The purpose of this report is to describe the results of an experimental study conducted at NBS during 1978 in which a $7 \mathrm{~m}^{3}$ ( $250 \mathrm{ft}^{3}$ ) pebble-bed and a $264 \mathrm{MJ}(250,000 \mathrm{Btu})$ phase-change unit utilizing sodium sulfate decahydrate, both using air as the transfer fluid, were tested in accordance with Standard 94-77. The study demonstrates the applicability of the Standard to both sensible-heat and latent-heat storage devices. A similar experiment was previously completed on a $1.9 \mathrm{~m}^{3}$ (500 gal) water tank. $[7,8]$.

It should be noted that a similar and parallel process has occurred with the NBS-recommended test procedure for solar collectors [1]. ASHRAE Standard 93-77 - Methods of Testing to Determine the Thermal Performance of Solar Collectors was adopted and published in February, 1977 [9]. NBS has conducted a series of experiments demonstrating the use of this standard for typical commercially available water-heating and air-heating collectors $[10,11]$. 


\section{ASHRAE STANDARD 94-77}

The tests outlined in ASHRAE Standard 94-77 consist of the following:

1. one test to determine a heat loss factor for the thermal energy storage device,

2. two tests to determine the response characteristics (charge capacity) of the device to a step increase (above the initial temperature) in the entering transfer fluid temperature, and

3. two tests to determine the response characteristics (discharge capacity) of the device to a step decrease (below the initial temperature) in the entering transfer fluid temperature.

\section{Heat Loss Test}

The heat loss test consists of passing the transfer fluid through the storage device with an inlet temperature of $25^{\circ} \mathrm{C}\left(45^{\circ} \mathrm{F}\right)$ above the ambient air temperature. After steady-state conditions are reached, measurements are made of the average temperature difference between the inlet and outlet transfer fluid and the ambient air temperature over a one-hour period (see Figure 1). Steady-state conditions are achieved by circulating the transfer fluid through the storage device until the inlet and outlet transfer fluid temperatures vary by less than $\pm 0.5^{\circ} \mathrm{C}$ $\left( \pm 0.9^{\circ} \mathrm{F}\right)$ during a one-hour period.

The heat loss factor is defined in the Standard by:

$$
\left.L=\frac{w_{L} c_{t f}}{(3600 s)\left(25^{\circ} \mathrm{C}\right)} \int_{\tau=0}^{\tau=} t_{i n}^{3600}-t_{\text {out }}\right) d \tau
$$

where

$$
\begin{aligned}
& \mathrm{L}=\text { heat loss factor, } \mathrm{J} /\left(\mathrm{s}^{\circ}{ }^{\circ} \mathrm{C}\right)\left(\mathrm{Btu} /\left(\mathrm{h}^{\circ}{ }^{\circ} \mathrm{F}\right)\right) \\
& \mathrm{w}_{\mathrm{L}}=\text { mass flow rate of the transfer fluid for the heat loss test, } \\
& \mathrm{kg} / \mathrm{s}(1 \mathrm{~b} / \mathrm{h}) \\
& c_{t f}=\text { specific heat of the transfer fluid, } \mathrm{J} /\left(\mathrm{kg}{ }^{\circ} \mathrm{C}\right)\left(\mathrm{Btu} /\left(1 \mathrm{~b}^{\circ}{ }^{\circ} \mathrm{F}\right)\right) \\
& t_{\text {in }}=\text { temperature of the transfer fluid entering the storage } \\
& \text { device, }{ }^{\circ} \mathrm{C}\left({ }^{\circ} \mathrm{F}\right) \\
& \mathrm{t}_{\text {out }}=\text { temperature of the transfer fluid leaving the storage }
\end{aligned}
$$

The mass flow rate of the transfer fluid to be used for the heat loss test is determined by:

$$
w_{L}=\frac{\mathrm{TSC}_{\mathrm{L}}}{\mathrm{c}_{\mathrm{tf}}(14400 \mathrm{~s})\left(25^{\circ} \mathrm{C}\right)}
$$




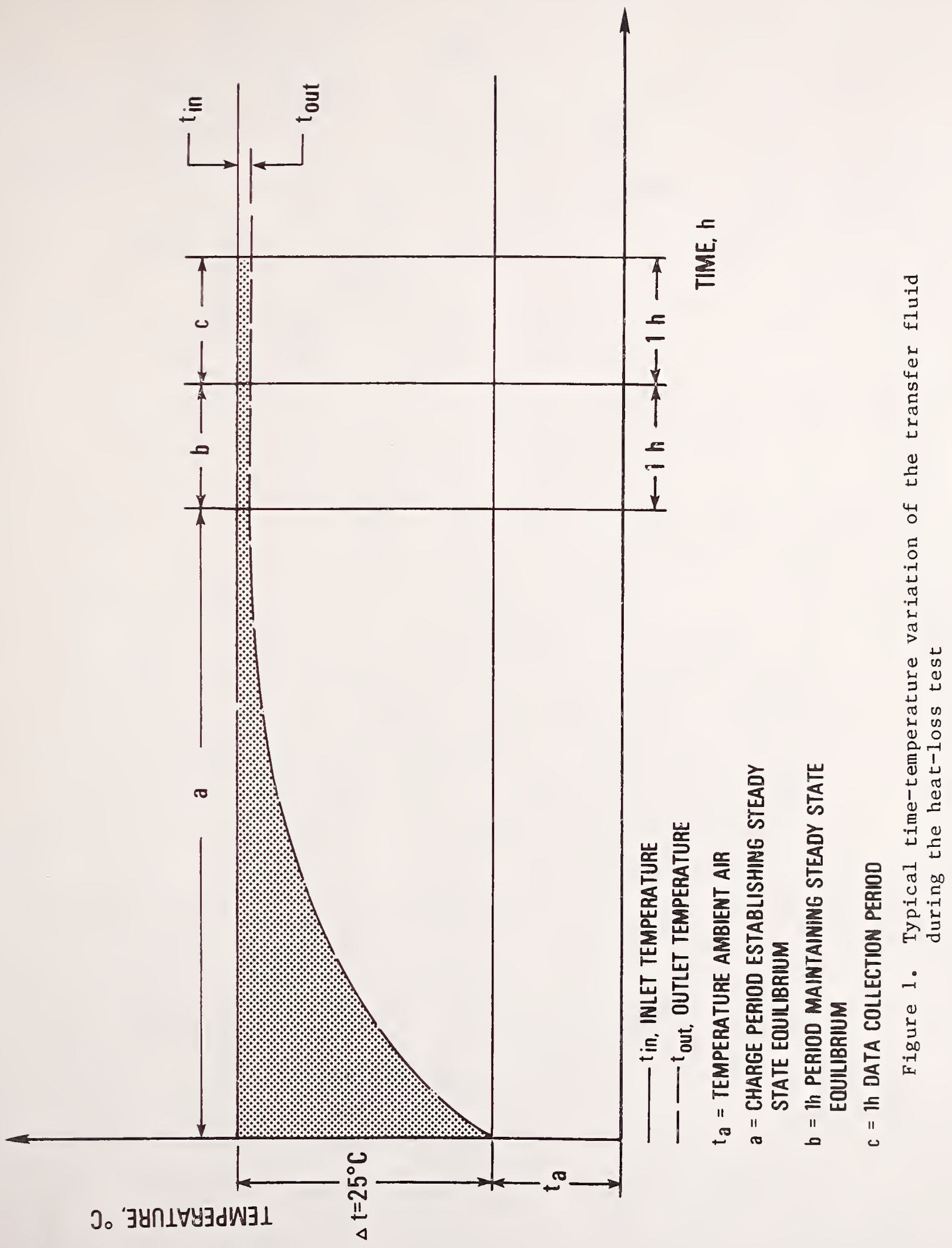


where

$\mathrm{TSC}_{\mathrm{L}}=$ theoretical storage capacity of the thermal energy storage device for the heat loss test, J (Btu).

The theoretical storage capacity for the heat loss test, $\mathrm{TSC}_{\mathrm{L}}$, is the amount of energy that could be stored in the device if all the device components would undergo an increase in temperature of $25^{\circ} \mathrm{C}\left(45^{\circ} \mathrm{F}\right)$, starting with an initial temperature equal to $t_{a}$, the ambient air temperature. It is further specified that it be calculated as the summation of the product of mass and specific heat of the various components comprising the device (storage medium, container, insulation, etc.) multiplied by the temperature increase of $25^{\circ} \mathrm{C}\left(45^{\circ} \mathrm{F}\right)$.

Charge and Discharge Tests

The concept of test fill time is introduced and defined in the Standard as:

$$
\tau_{f}=\frac{T S C}{{ }^{t f f} c_{t f} \Delta t}
$$

where

$$
\begin{aligned}
\tau_{\mathrm{f}}= & \text { test fill time, } \mathrm{s} \\
\mathrm{TSC}= & \begin{array}{l}
\text { theoretical storage capacity of the thermal energy storage } \\
\text { device for the temperature increase } \Delta t, \mathrm{~J} \text { (Btu) }
\end{array} \\
\mathrm{w}_{\mathrm{tf}=} & \text { mass flow rate of the transfer fluid, } \mathrm{kg} / \mathrm{s}(\mathrm{lb} / \mathrm{h}) \\
\Delta t= & \begin{array}{l}
\text { temperature step of the inlet transfer fluid from an initial } \\
\text { temperature, } t_{i}, \text { to a final temperature, } t_{i} \pm \Delta t,{ }^{\circ} \mathrm{C}\left({ }^{\circ} \mathrm{F}\right) .
\end{array}
\end{aligned}
$$

A sensible heat storage device with no heat loss to the ambient and with perfect stratification of the storage medium would be completely charged or discharged in the time defined by equation ( 3 ). Since such an ideal storage device does not exist, the fill time defined above is found to be less than the time required to completely charge or discharge actual storage devices. In the original analysis that led to the proposed test procedure, several alternate ways of specifying the test period and/or flow rate to be used were considered $[1,3]$. It was concluded that thermal energy storage devices of widely differing designs could be equitably compared if each were tested for the same period of time defined by equation (3). In other words, the flow rates for the different devices are adjusted so that the amount of energy entering or leaving the device (denominator of equation (3)) per unit thermal energy storage capacity (numerator of equation (3)) is the same for each device.

The Standard specifies that the charge and discharge tests be conducted for specific test fill times and step changes in the inlet temperature of the transfer fluid. The recommended temperature step change values 
for devices which use both air and liquid were based on consideration of the way in which they are currently used in typical solar heating and cooling systems. The fill times were chosen based on typical ratios of solar collector size to storage size and flow rates required for optimum collector performance [5]. However, as a result of the experiments described in this report, it has been found that the air flow rates recommended by the Standard are much too high.

The recommended values specified in the Standard for devices using air as the transfer fluid are:

$$
\begin{aligned}
\tau_{\mathrm{c}}, \tau_{\mathrm{d}} & =2 \mathrm{~h} \\
\Delta t & =35^{\circ} \mathrm{C}\left(63^{\circ} \mathrm{F}\right)
\end{aligned}
$$

and

$$
\begin{aligned}
\tau_{\mathrm{c}}, \tau_{\mathrm{d}} & =4 \mathrm{~h} \\
\Delta t & =35^{\circ} \mathrm{C}\left(63^{\circ} \mathrm{F}\right)
\end{aligned}
$$

where the subscripts $c$ and $d$ denote the charge tests and discharge tests, respectively. With the test fill times designated, the mass flow rates are determined by the use of equation (3). Therefore, the mass flow rates for the transient tests are determined by:

$$
\begin{aligned}
& w_{c}=\frac{T S C}{{ }^{\tau} c_{t f} \Delta t} \\
& w_{d}=\frac{T S C}{{ }^{{ }_{d} c_{t f} \Delta t}}
\end{aligned}
$$

In cases where the storage device was designed for a particular flow rate, the Standard allows use of this design flow rate.

Figure 2 represents the charge and discharge cycles of a thermal energy storage device undergoing the transient response tests in accordance with the Standard. The initial temperature of the storage medium is chosen based on the intended operating range of the device. The flow is adjusted to the value, $w_{C}$, defined by equation (4), and the device is brought to a uniform initial temperature. The temperature of the entering transfer fluid is then raised in a step-like manner from the initial temperature, $t_{i}$, to a final temperature, $t_{i}+\Delta t$, and measurements necessary for computing the charge capacity are made over the charge test fill time, ${ }^{\tau} c$. The storage medium is then allowed to reach steady-state conditions at the temperature $t_{i}+\Delta t$. Once steady-state conditions are obtained, a discharge test is performed by decreasing the entering transfer fluid temperature in a step-like manner from $t_{i}+\Delta t$ to a value of $t_{i}$. Measurements necessary in computing the discharge capacity are then recorded over the discharge test fill time, $\tau_{d}$. The measurements 


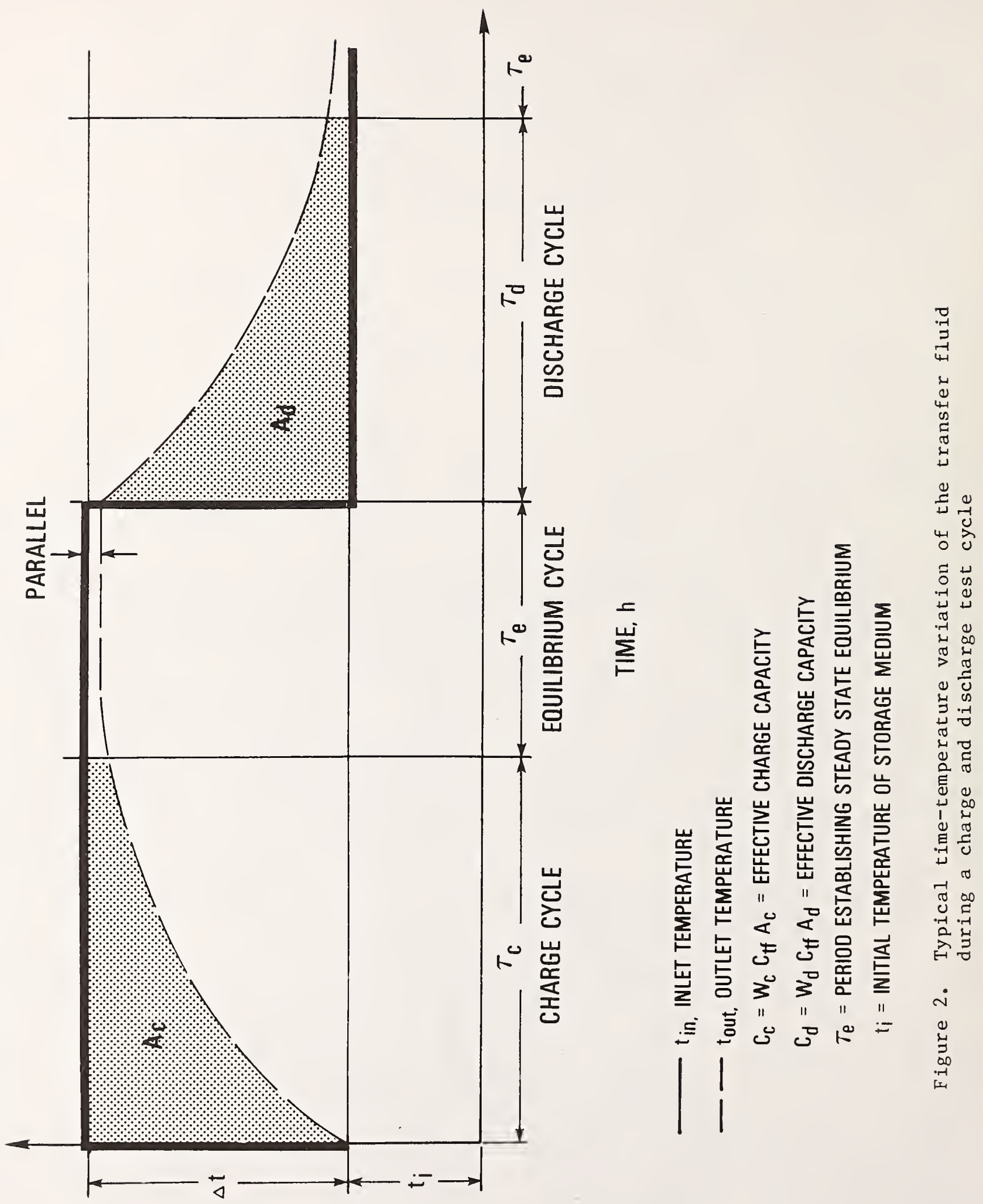

ว。 ' $\exists \forall \cap \perp \forall \forall \exists d W \exists \perp$ 
required for the charge and discharge test computations are the temperature difference between the entering and leaving transfer fluid over the test fill time, the transfer fluid flow rate, and the ambient air temperature.

The charge and discharge capacities are computed as:

$$
\begin{aligned}
& c_{c}=w_{c} c_{t f} \int_{\substack{\tau=0 \\
\tau}}^{\tau_{c}}\left(t_{\text {in }}-t_{\text {out }}\right) d \tau-L \tau_{c}\left(t_{i}+\frac{\left.\overline{t_{\text {in }}-t_{\text {out }}}-t_{a}\right)}{2}\right. \\
& \text { and } \\
& c_{d}=w_{d} c_{t f} \int_{\tau=0}^{\tau=\tau_{d}}\left(t_{\text {out }}-t_{\text {in }}\right) d \tau,
\end{aligned}
$$

where

$$
\begin{aligned}
& C_{c}= \text { charge capacity of the thermal energy storage device, } \\
& \mathrm{J} \text { (Btu) } \\
& C_{d}= \\
& \begin{array}{l}
\text { discharge capacity of the thermal energy storage device, } \\
\text { (Btu }
\end{array}
\end{aligned}
$$

It should be noted that the charge and discharge capacities are a function of the specific heat of the transfer fluid and hence a function of the transfer fluid used.

\section{NBS TEST FACILITY}

The tests conducted and described in this paper were performed on a $7 \mathrm{~m}^{3}$ (264 $\left.\mathrm{ft}^{3}\right)$ pebble-bed and a $264 \mathrm{MJ}(250,000 \mathrm{Btu})$ phase-change unit at the NBS site in Gaithersburg, Maryland.

\section{Phase-Change Unit}

The phase-change device consisted of 726 plastic trays containing a Glauber Salt-water mixture (sodium sulfate decahydrate). The phasechange temperature for this material is $32^{\circ} \mathrm{C}\left(89^{\circ} \mathrm{F}\right)$. Tray dimensions and manufacturer's specifications are shown in Figure 3 . The trays were arranged in an array 26 trays high, 4 trays wide, and 7 trays in the flow direction. The array tested was short two trays. The tray array was contained within a $1.3 \mathrm{~cm}(1 / 2 \mathrm{in})$ plywood cell arrangement which was insulated on the outside with $15 \mathrm{~cm}$ ( 6 in) of foamed insulation. Air was the heat transfer fluid used with this device. Figure 4 shows a schematic of the test specimen. 


\section{SPECIFICATIONS}

EUTECTIC SALT:

- Sodium Sulfate Decahydrate $\mathrm{NA}_{2} \mathrm{SO}_{4}-10 \mathrm{H}_{2}$ )

- Latent heat of fusion

$112 \mathrm{MJ} / \mathrm{m}^{3}$ at $32^{\circ} \mathrm{C}$

- Density-1458 kg/m ${ }^{3}$

o Specific heat: $\quad \mathrm{kJ} /(\mathrm{kg} \cdot \mathrm{K})$
CONTAINER :

o High density polyethylene

- Density-0.96 gms/cc

- Products of combustion- $\mathrm{CO}_{2}+\mathrm{H}_{2} \mathrm{O}$

- Flash point $-340^{\circ} \mathrm{C}$

- Coefficient of linear expansion$.0013 \mathrm{~m} / \mathrm{m}^{\circ} \mathrm{C}$

o Thermal conductivity-0.53 $\mathrm{W} /(\mathrm{m} \cdot \mathrm{K})$
Saturated at $32^{\circ} \mathrm{C}$

3.26

Solution of $\mathrm{NA}_{2} \mathrm{SO}_{4}$

3.51

4.18

o Specific heat-0.458 cai/gm

- Nomina1 wa11 thickness-0.05 cm

Water

- Sonic sealing

- Empty weights-250 grams each

o Ful1 weight-1724 grams each

o Volume per tray-1019 cc

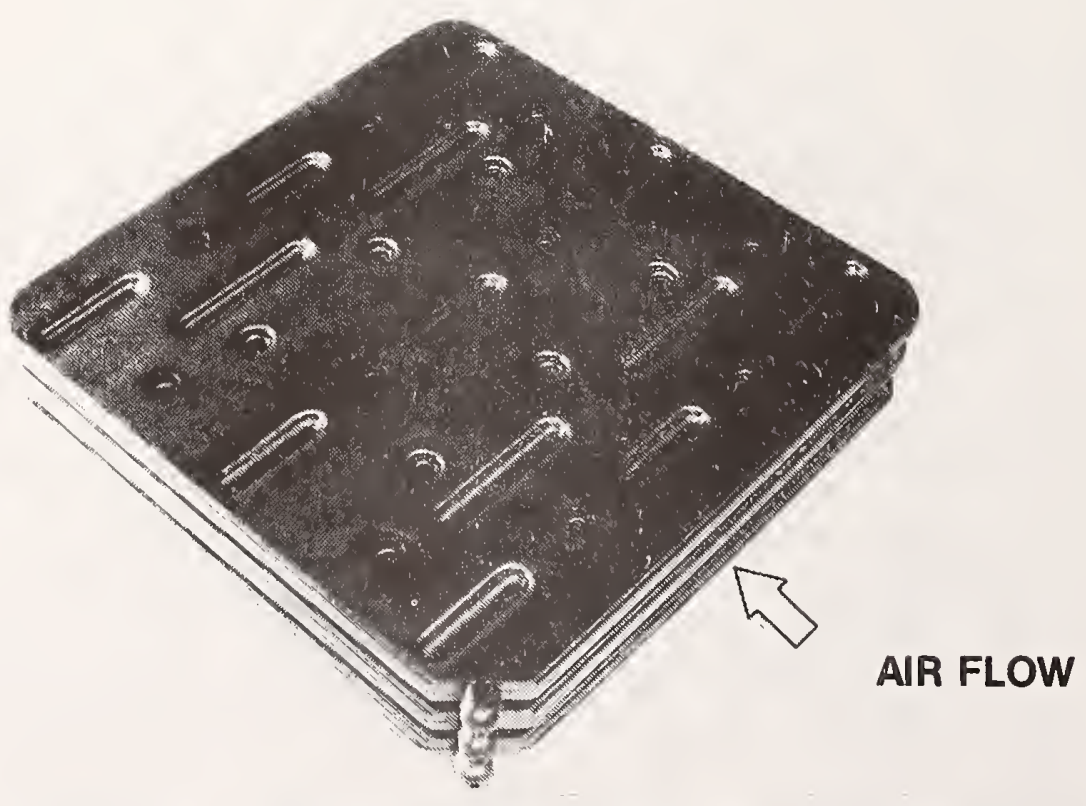

Figure 3. Phase-change thermal energy storage tray and eutectic material specifications 


\section{PHASE-CHANGE THERMAL ENERGY STORAGE UNIT}

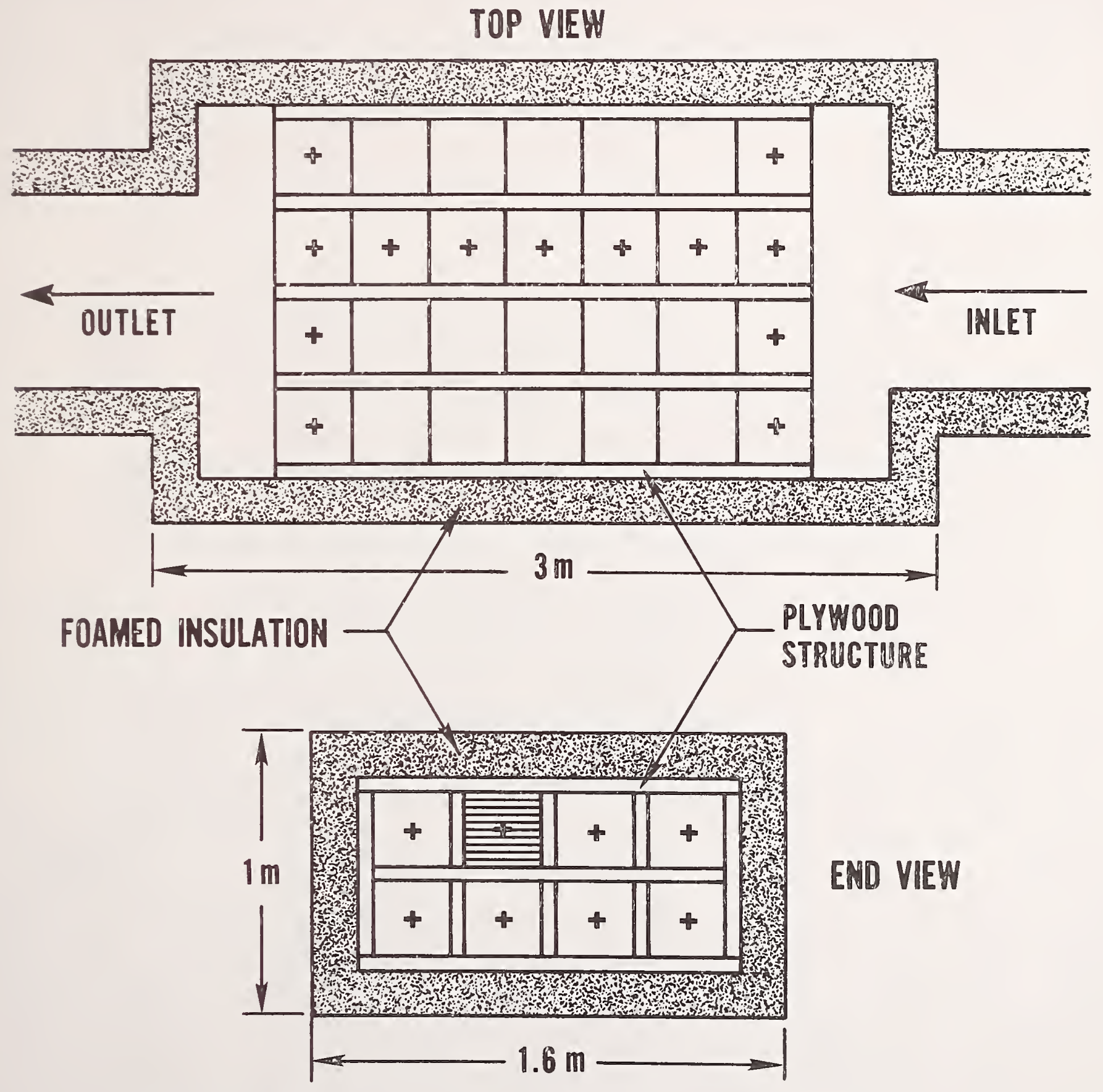

THERMOCOUPLE LOCATIONS

Figure 4. Schematic of the phase-change thermal energy storage test unit 
The nominal thermal energy storage capacity of the unit was $264 \mathrm{MJ}$ $(250,000 \mathrm{Btu})$ although the actual capacity would vary according to temperature swing and the exact number of trays. A theoretical energy storage capacity of $414 \mathrm{MJ}(392,000 \mathrm{Btu})$ was calculated using the manufacturer's specifications and a temperature swing of $35^{\circ} \mathrm{C}\left(63^{\circ} \mathrm{F}\right)$ chosen in accordance with Standard 94-77 and used during the test. The thermal energy storage capacity is a combination of the latent-heat and sensibleheat capacity of the storage material. Table 1 summarizes the thermal energy storage contribution of the various components. The theoretical latent contribution was approximately 65 percent of the total capacity。

$\underline{\text { Pebble-Bed }}$

The pebble-bed was fabricated at NBS from plans shown in Figure 5. The pebble-bed container was constructed using $1.27 \mathrm{~cm}(0.5 \mathrm{in})$ plywood and $4 \times 10 \mathrm{~cm}$ ( $2 \times 4 \mathrm{in})$ studs with $8 \mathrm{~cm}$ (3 in) glass fiber batts between the studs. Building sealant and duct tape were used on all joints. The upper air flow plenum was formed by leaving a $20 \mathrm{~cm}$ ( 8 in) space between the rocks and the top of the container. The lower air flow plenum was formed using blocks as shown covered with a heavy metal screen. The pebble-bed was composed of 3.8 to $5 \mathrm{~cm}$ (1.5 to $2 \mathrm{in}$ ) washed river gravel from a local source. After construction, it was necessary to seal all external seams with an industrial epoxy tape sealant in order to stop the air leakage. The internal dimensions of the pebble bed were $2 \mathrm{~m}$ by $2 \mathrm{~m}(6.5 \mathrm{ft}$ by $6.5 \mathrm{ft})$ in horizontal cross-section and $1.8 \mathrm{~m}(6 \mathrm{ft})$ in height. The pebble bed is shown in Figure 6 as it was tested. The flow direction was from top to bottom during all tests.

The thermal energy storage capacity of the pebble-bed was $9.80 \mathrm{MJ} /{ }^{\circ} \mathrm{C}$ $\left(5160 \mathrm{Btu} /{ }^{\circ} \mathrm{F}\right)$ computed from the bed dimensions and assuming a rock density of $1538 \mathrm{~kg} / \mathrm{m}^{3}\left(96 \mathrm{lb} / \mathrm{ft}^{3}\right)$ and a specific heat of $0.88\left(\mathrm{~kJ} / \mathrm{kg}^{\circ}{ }^{\circ} \mathrm{C}\right)$ $\left(0.21 \mathrm{Btu} /\left({ }^{\circ} \mathrm{F} \cdot \mathrm{lb}\right)\right.$ ) for the rock. Using the $35^{\circ} \mathrm{C}\left(63^{\circ} \mathrm{C}\right)$ temperature swing, the theoretical energy storage capacity was $343 \mathrm{MJ}(325,000 \mathrm{Btu})$. The latent energy storage effects due to moisture exchange with the air stream, to be described later in this report, were not taken into account in calculating the theoretical storage capacity.

\section{Test Loop}

The test loop is shown schematically in Figure 7. Room air first entered a proportionally-controlled $25 \mathrm{~kW}$ electric duct heater, where it was heated to the desired test temperature. The conditioned air traveled from the heater through a length of flexible ducting to the upstream measurement section, the thermal energy storage device (TESD), and the downstream measurement section. The measurement sections contained pressure taps for pressure measurements across the TESD, sensors for wet-and dry-bulb temperature measurements, and a thermopile across the two sections for temperature difference measurements. Another section of flexible ducting was connected from the downstream measurement section to a blower-nozzle arrangement which was used to measure air flow. Air was exhausted from the blower to outside the test cell to avoid over-heating problems. 


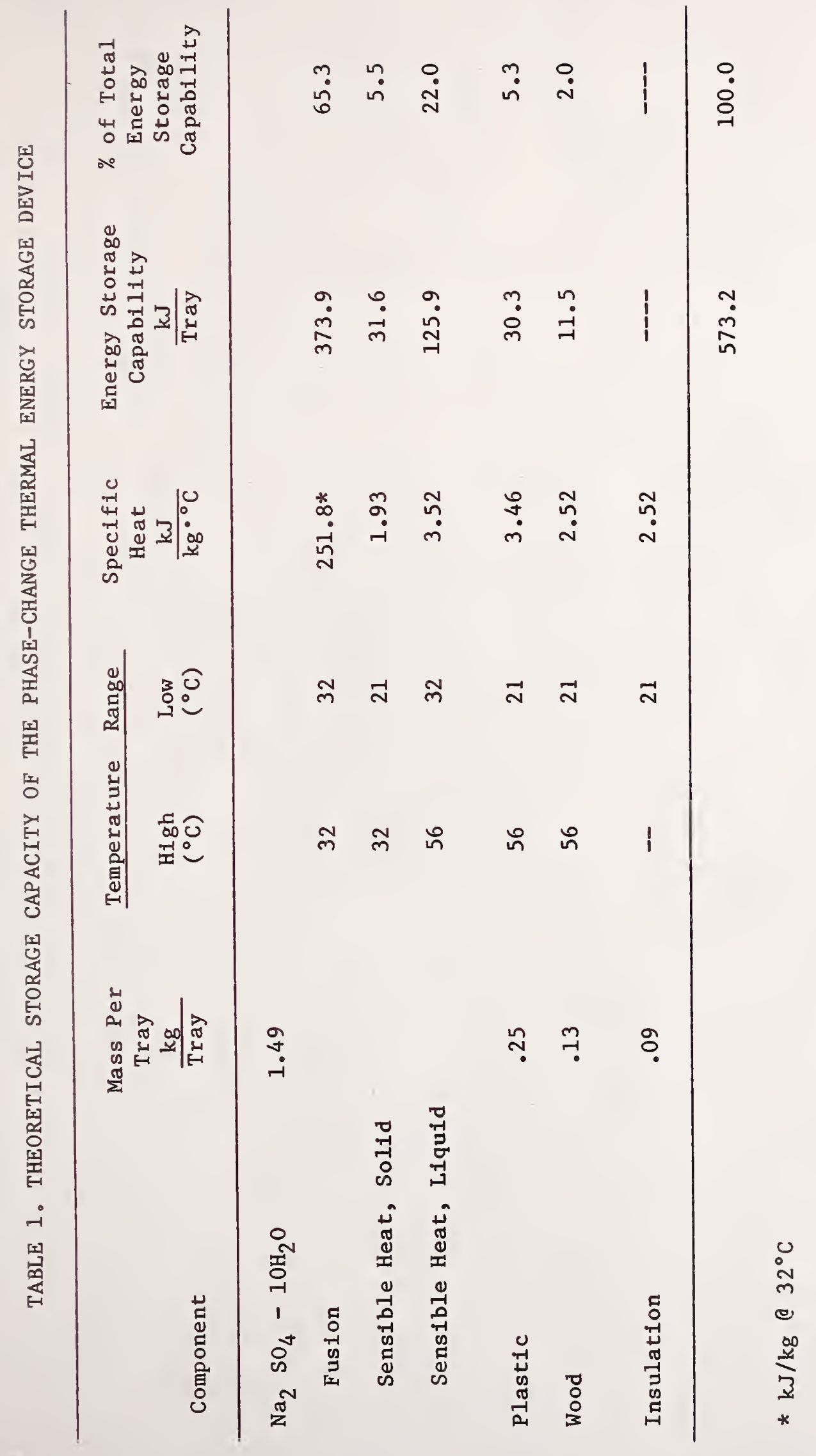




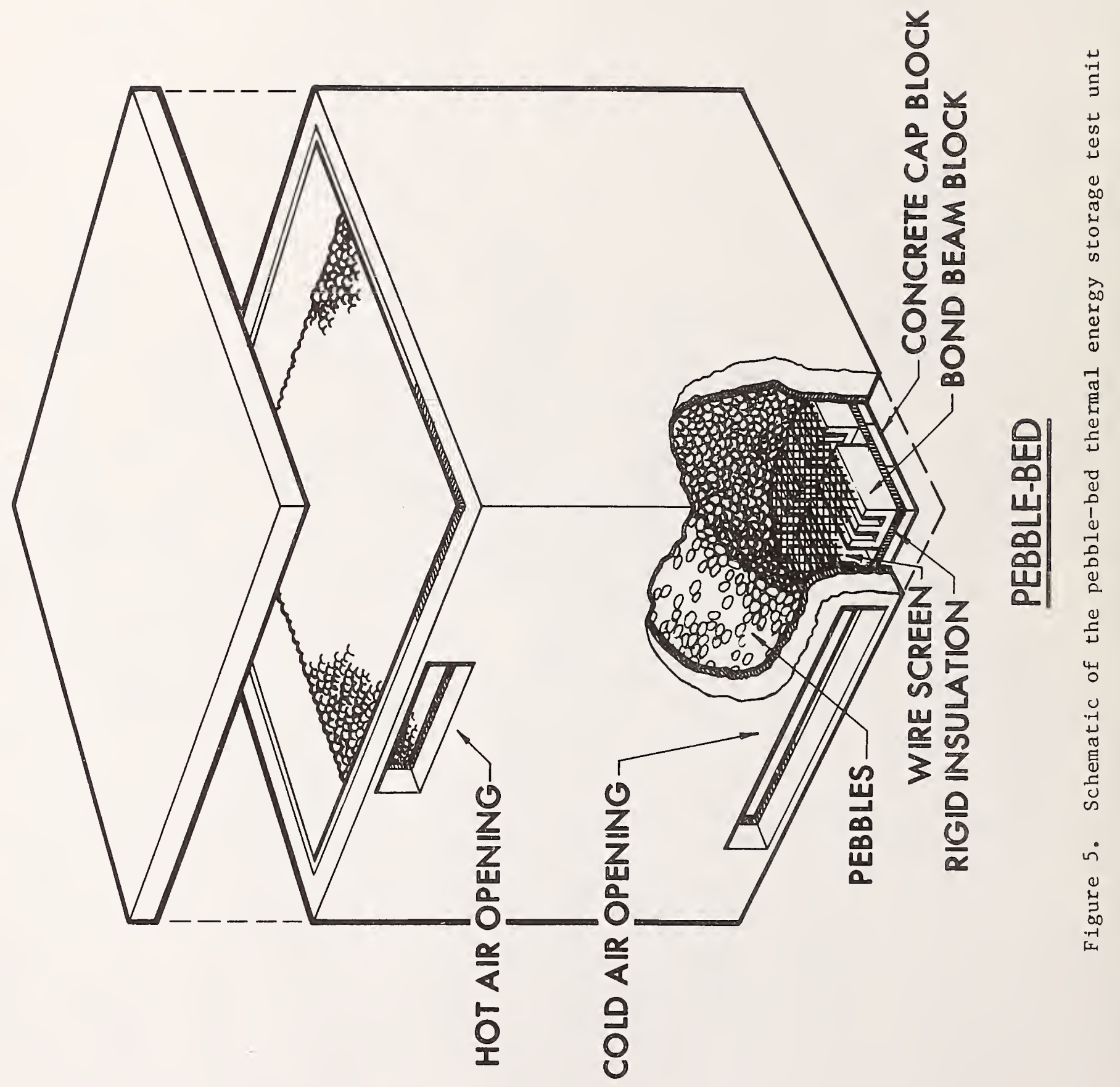




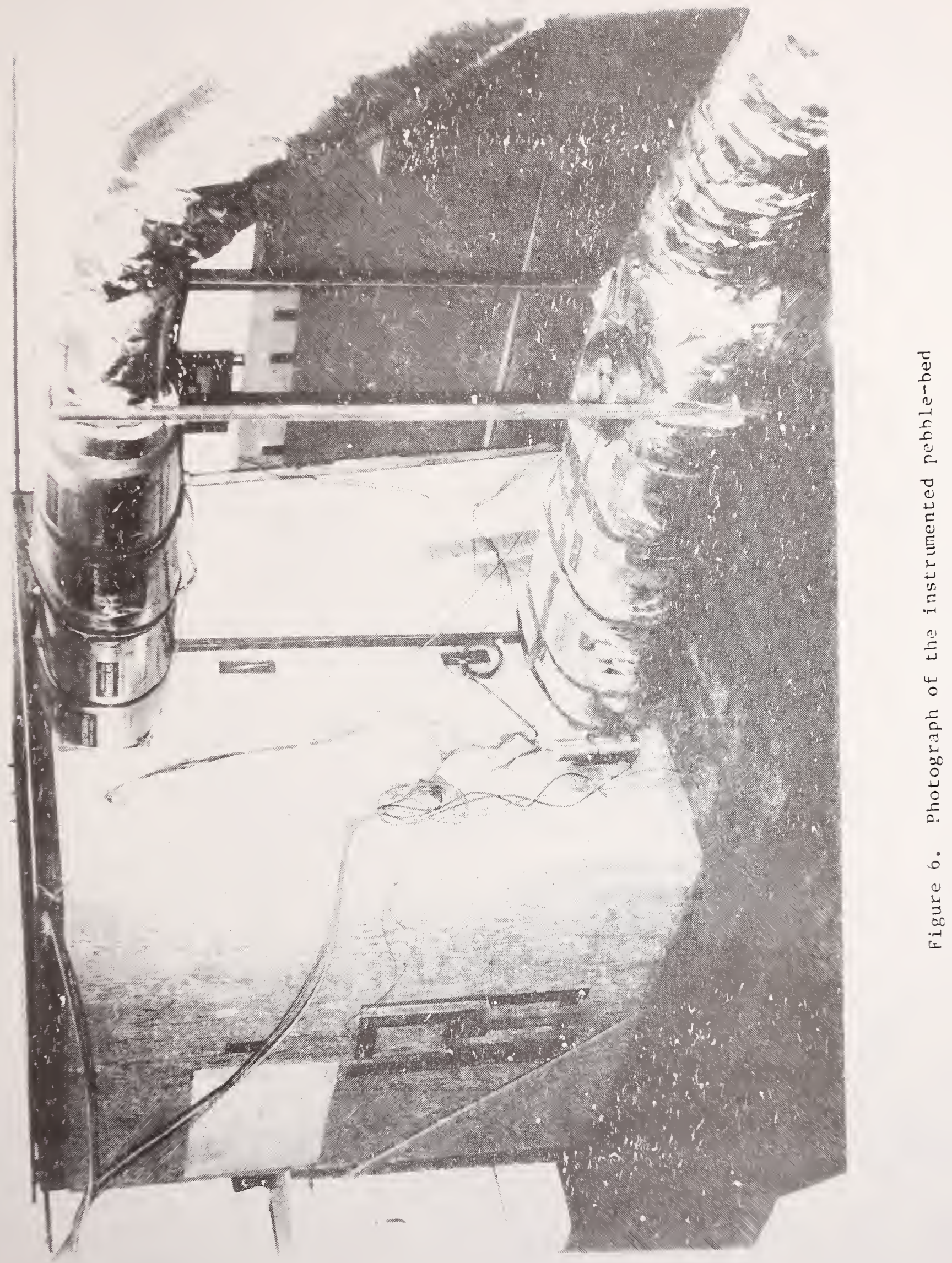




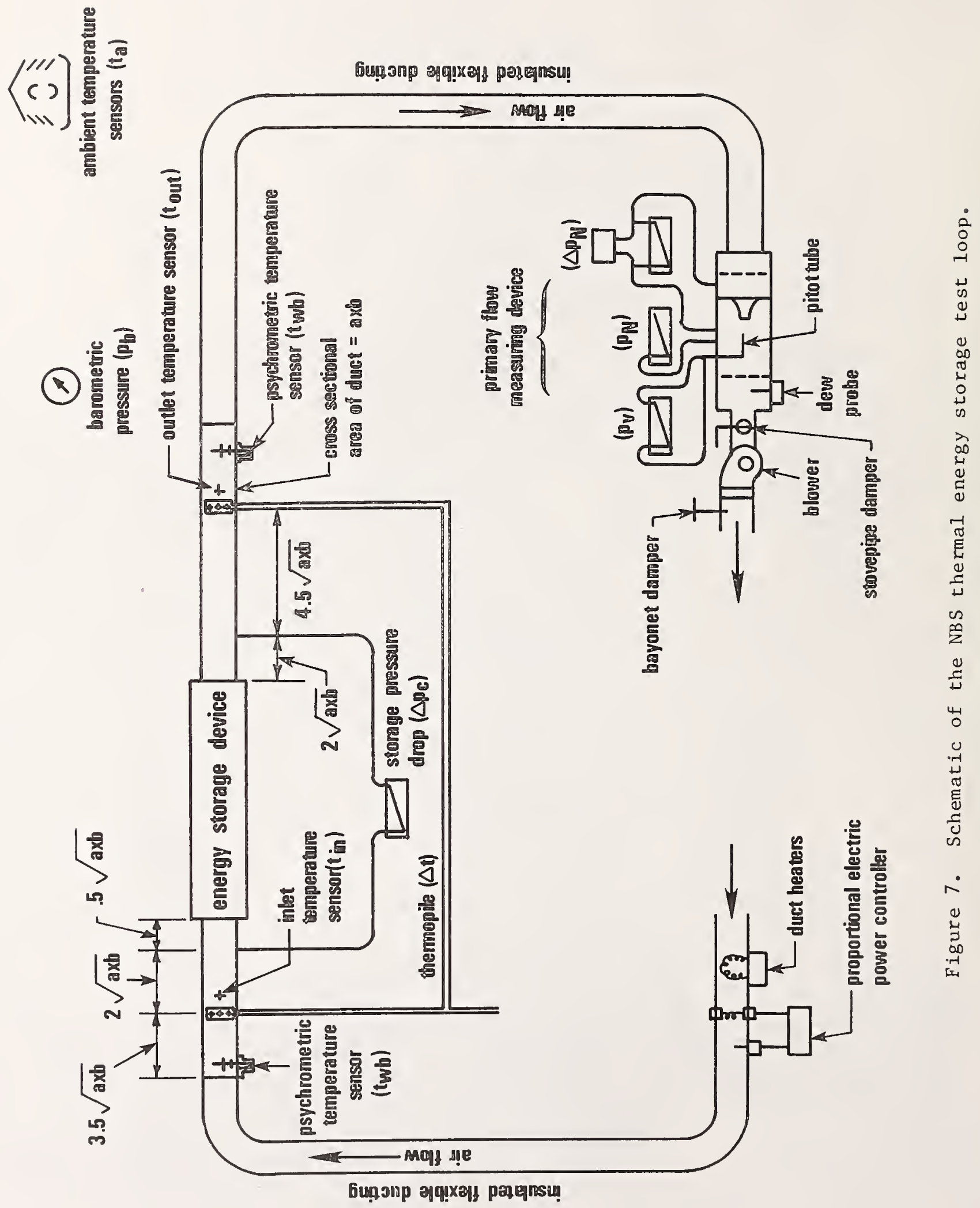


The measurement sections approximated typical duct size ratios and we re constructed in accordance with the requirements of Standard 94-77 with respect to pressure taps and placement of sensors as shown in Figure 7 . Thermocouples were used for dry-bulb temperature measurements and a wet-bulb thermocouple (Figure 8 ) was used for wet-bulb temperature measurements [12]. A six-junction thermopile was used for temperature difference measurements. Thermccouples and the thermopile were all laboratory fabricated from premium 24-gage type-T thermocouple wire. Both duct sections were heavily insulated with $15 \mathrm{~cm}$ (6 in) of glass fiber insulation. Flow mixers were not used.

Several methods were employed for measuring air stream humidity during the various tests. The first technique was to place psychrometers in both the inlet and exit air flow ducts. The psychrometers consisted of wet-and dry-bulb temperature sensing type-T thermocouples and were constructed and applied as specified in ASHRAE Standard 41.1-74 [12]. After the tests were completed on the pebble-bed and the data reduced, it was found that the inlet duct psychrometer indicated a sudden increase in absolute humidity ratio when the dry-bulb temperature was suddenly increased by the electric heater. This indicates that the inlet psychrometer was not reading properly since moisture was not being added to the air stream. Noting this effect from the data, the test duct was disconnected and inspected and the inlet wet-bulb sensing element was found to be resting on a rubber stopper. Apparently the supporting thermocouple wire had slipped. It was also noted that the outlet wet-bulb sensor was dirty, probably due to dust from the pebble bed. As a result, the wet-bulb readings for the pebble bed tests were not reliable.

An error sensitivity analysis was conducted for the psychrometer in order to gain insight into the problem of the psychrometric measurements for these tests. For a properly wetted wet-bulb temperature sensing element, errors in specific humidity were calculated to be in the range of 5 to 10 percent at low relative humidities due to radiation heat exchange between duct walls and the wet-bulb element. Radiation effects can be compensated for fairly accurately; however, they are generally ignored. Further analysis indicated that a $0.5^{\circ} \mathrm{C}\left(1^{\circ} \mathrm{F}\right)$ measurement error in the inlet wet-bulb temperature at conditions present during the tests would result in a $7 \%$ error in inlet specific humidity and a $6 \%$ error in the energy exchange across the thermal energy storage device.

A second type of sensor used on the outlet of the pebble-bed was a commercial relative humidity transducer which depends on the absorbic equilibrium properties of lithium chloride for its response. During the first charge test on the pebble-bed, the relative humidity transducer gradually drifted to a reading of $0 \%$ relative humidity and remained there for the rest of the tests. The drift was probably due to fouling of the element caused by dust from the bed.

A third type of sensor employed was a "dew-probe" which measures the dew point temperature of the air. In this device, a mirrored surface is cooled until the surface starts to fog. A photoelectric sensor is used 


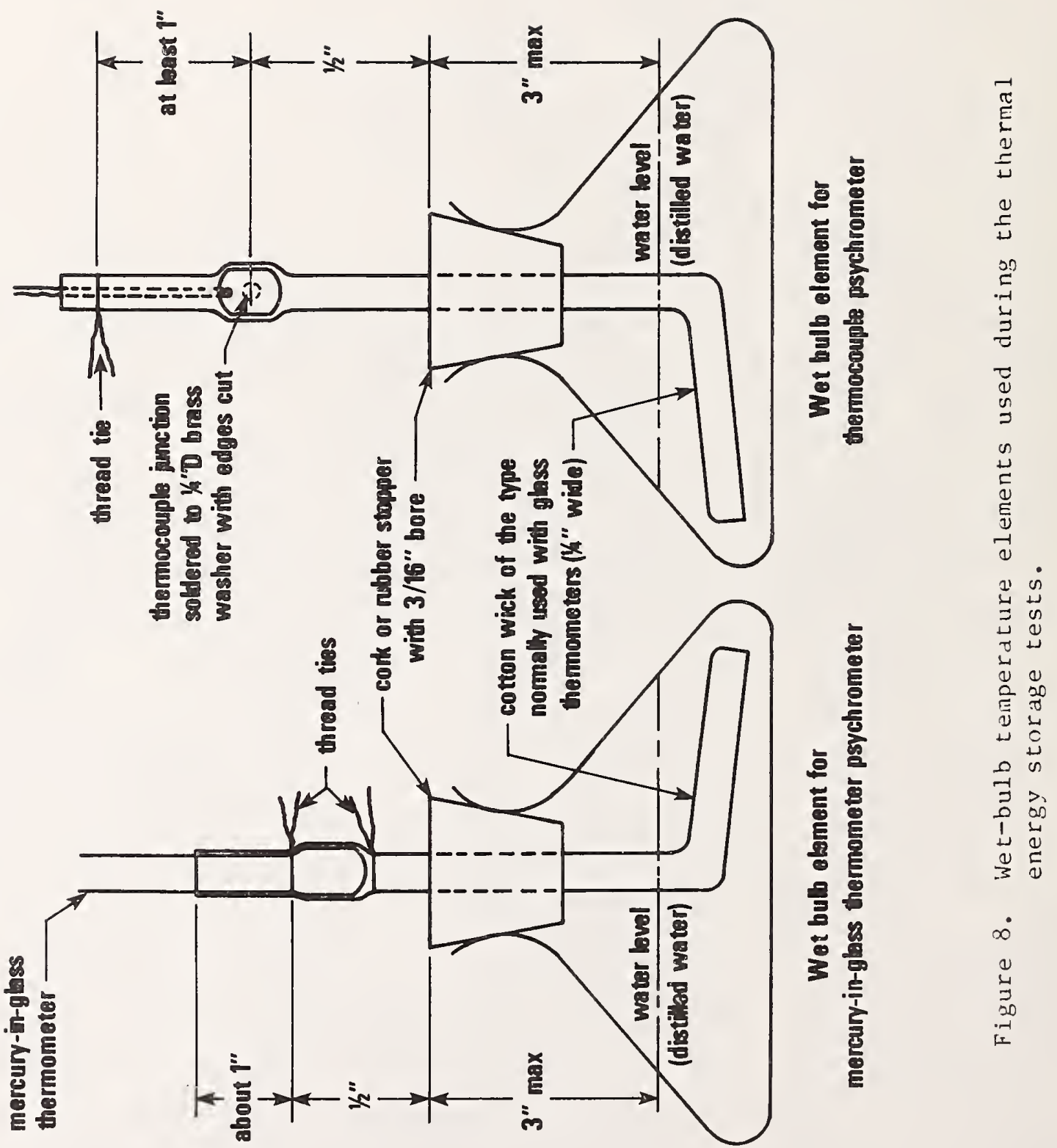


to maintain the surface temperature at the dew-point and a thermocouple indicates temperature. This device is considered more reliable than the transducer even though it can be contaminated by foreign substances in the air. It was not available for the pebble-bed tests.

The flow measuring apparatus was a blower nozzle arrangement built in accordance with Standard 94-77. Flexible magnetic mounting strips were fixed to the nozzles and worked in combination with the air pressure to hold the nozzle in place and form a tight seal. Five interchangeable nozzle sizes were available: $5,6.5,7.5,10$, and $12.5 \mathrm{~cm}(2,2.5,3$, 4 , and $5 \mathrm{in}$ ) throat diameters, which provided a range of flow rates from 0.03 to $0.41 \mathrm{~m}^{3} / \mathrm{s}\left(70\right.$ to $\left.950 \mathrm{ft}^{3} / \mathrm{min}\right)$. The pressure difference across the nozzle was determined using a $0-1.2 \mathrm{kPa}\left(0-5\right.$ in $\left.\mathrm{H}_{2} \mathrm{O}\right)$ inclined manometer in parallel with an electronic pressure transducer. The pressure transducer was an elastic diaphragm type. The nozzle discharge gauge pressure was determined using a $0-2.5 \mathrm{kPa}\left(0-10\right.$ in $\left.\mathrm{H}_{2} 0\right)$ vertical manometer. A precision barometer was used to measure barometric pressure.

The blower was a centrifugal industrial model with a 3 phase, 220-Volt, 3 -horsepower motor capable of delivering $0.47 \mathrm{~m}^{3} / \mathrm{s}\left(1000 \mathrm{ft}^{3} / \mathrm{min}\right)$ at standard conditions and at a static head of $2.5 \mathrm{kPa}\left(10\right.$ in $\left.\mathrm{H}_{2} 0\right)$. In a typical sola: heating system installed in a house, a half-horsepower or smaller motor is generally sufficient since air flow nozzles are not used. The major pressure loss experienced in the tests was 0.25 to 0.75 $\mathrm{kPa}$ ( 1 to 3 in $\mathrm{H}_{2} 0$ ) pressure drop across the nozzle. The amount of air delivered by the blower was controlled by a bayonet-type damper on the blower outlet (coarse control) and a stovepipe-type damper on the inlet (fine control). The blower assembly was mounted on rubber vibration isolators and duct connections to the blower were made using flexible rubber connections which resulted in nearly complete vibration isolation of the blower.

Data from the various sensors consisted of either millivolt signals (thermopile and pressure transducer) or thermocouple signals, which were fed to a commercial data aquisition system (DAS). The DAS was capable of handling 20 millivolt channels and 40 thermocouple channels. The scan rate was variable, although all tests were done at a 2 -minute scan rate. An internal electronic reference junction was used for thermocouples. Data were collected and stored on a reel-to-reel magnetic tape drive and data reduction was accomplished on the large-scale digital computer at NBS.

The remainder of the instrumentation for these tests consisted of four thermocouples for ambient temperature measurement and thermocouples located within the thermal energy storage units. The pebble-bed was instrumented with 13 thermocouples placed along a line through the center in the direction of flow. The phase change unit was similarly instrumented with seven thermocouples for air temperature through the centerline, seven thermocouples for tray temperature through the centerline, and other thermocouples scattered throughout the unit. 
Prior to any testing, the thermal energy storage units were subjected to a smoke test to determine if air leaks were present. The smoke test consisted of pressurizing the units to about $0.25 \mathrm{kPa}\left(1\right.$ in. $\mathrm{H}_{2} 0$ ), introducing smoke from a smoke bomb into the unit, and visually checking for leaks. This method was found to detect very small leaks.

\section{EXPERIMENTAL PROCEDURE}

\section{Heat Loss Test}

The heat loss test was carried out in accordance with Standard 94-77 except for using a temperature difference of $35^{\circ} \mathrm{C}\left(63^{\circ} \mathrm{F}\right)$ rather than $25^{\circ} \mathrm{C}\left(45^{\circ} \mathrm{F}\right)$ as specified. The reason for this departure was that it was more convenient to do the heat loss test at the end of a charge test which was done at $35^{\circ} \mathrm{C}$. It was felt this would not compromise the cest results in any way. All test cycles described in this report consisted of a charge test followed by a heat loss test and finally followed by a discharge test.

For the heat loss test, the inlet fluid temperature was set at $35^{\circ} \mathrm{C}$ $\left(63^{\circ} \mathrm{F}\right)$ above ambient temperature and the outlet fluid temperature was allowed to reach a steady-state condition. The difference between inlet and outlet fluid temperatures was averaged over a several hour period. The heat loss coefficient, $L$, was then calculated according to the equation (1). A major problem with the heat loss test was found to be the stability and measurement of the low temperature difference across the unit. Typical ranges of temperature difference were 1.5 to $3^{\circ} \mathrm{C}$ ( 3 to $\left.6^{\circ} \mathrm{F}\right)$. The fluid inlet temperature controller was required to maintain a steady temperature only within $\pm 1^{\circ} \mathrm{C}\left( \pm 2^{\circ} \mathrm{F}\right)$ which made it very difficult to accurately measure the 1.5 to $3^{\circ} \mathrm{C}$ temperature difference. In order to overcome these problems, the heat loss rate was averaged over several hours rather than the one-hour test period as specified.

Transient Charge Tests

All transient tests were performed in accordance with the Standard except that the recommended flow rates were not used. Both thermal energy storage units were designed for specific flow rates and these specified flow rates were used in the tests. In general, the flow rates specified in the Standard are much higher than experienced in most solar systems using air as the transfer fluid. The Standard specifies fill times of 2 and 4 hours, whereas in a typical system the flow rate is such that the fill time is approximately 6 hours. A summary of all transient tests on both units is presented in Tables 2 and 3 , respectively.

Transient charge tests were performed by first circulating room temperature air through the device until the inlet and exit temperatures were within $0.5^{\circ} \mathrm{C}\left(1.0^{\circ} \mathrm{F}\right)$. The flow rate was then adjusted to the desired value and the air heaters were then turned on starting the test. The required test fluid inlet temperature was generally attained within 5 minutes, meeting the requirements of the Standard that $90 \%$ of the step change be achieved within $2 \%$ of the test fill time. The charge test 
continued until the exit fluid temperature reached steady-state conditions at which time the heat loss test was started. For all tests on the pebble-bed, the flow direction was top to bottom. Flow rates for all teşts in both units were approximately 0.42 and $0.21 \mathrm{~m}^{3} / \mathrm{s}$ (900 and $\left.450 \mathrm{ft}^{3} / \mathrm{min}\right)$.

\section{Transient Discharge Tests}

The transient discharge tests were performed following the heat loss tests. The flow rate was not adjusted prior to starting the discharge tests since adjusting flow rate could have caused problems with the stability of the inlet temperature. Thus the discharge test was started by simply cutting off the heaters and introducing unconditioned room temperature air.

An important exception to the ASHRAE test requirements for this test program was that the phase-change device was not cycled through the phasechange temperature 30 times prior to testing. Tests performed at NBS were primarily to evaluate the testing techniques and not to evaluate the particular unit.

\section{PHASE-CHANGE DEVICE TEST RESULTS}

Test on the phase-change unit were run at the NBS facility in July and August, 1978. Five complete charge - heat loss - discharge test cycles were completed, three at the flow rate recommended by the manufacturer and two at one-half the recommended flow rate. Air stream pressure drop across the device was $0.21 \mathrm{kPa}\left(0.85\right.$ in. $\left.\mathrm{H}_{2} 0\right)$ at the recommended flow rate.

\section{Heat Loss Test}

A heat loss test was included in all five test cycles and resulted in an overall heat loss coefficient of $85.5 \mathrm{~kJ} /\left(\mathrm{h}^{\circ}{ }^{\circ} \mathrm{C}\right)\left(45 \mathrm{Btu} /\left(\mathrm{h}{ }^{\circ} \mathrm{F}\right)\right)$ for both test flow rates. An estimation of the heat loss factor utilizing basic heat transfer theory, the material properties and dimensions of the phase-change container, and assuming no air leakage, yielded an overall heat loss coefficient of $17 \mathrm{~kJ} /\left(\mathrm{h}^{\circ}{ }^{\circ} \mathrm{C}\right)\left(9 \mathrm{Btu} /\left(\mathrm{h}^{\circ}{ }^{\circ} \mathrm{F}\right)\right)$. Heat loss during the transient tests generally was on the order of 5 to 10 percent of the energy transferred during a test fill time period.

A major heat loss problem in these types of thermal energy storage devices is air leakage to or from the unit. The storage container which was fabricated at the NBS site contained sealant which dried out and cracked shortly after installation. The unit had to be resealed and taped. Metal packing bands were necessary to hold the unit together. The dry wall recommended by the manufacturer was not used. Smoke tests verified the unit was sealed although there was some smoke diffusion through the foamed insulation. 
The results from the charge and discharge tests for the five test cycles of the phase-change unit are shown in Table 2. The charge capacity was found to be approximately $220 \mathrm{MJ}\left(2.1 \times 10^{5} \mathrm{Btu}\right)$ using the fill time as defined in Standard $94-77$ and described earlier in this report. A more meaningful measure of performance in the authors 'opinion is to divide the charge capacity by the theoretical storage capacity which yields an average value of 0.56 . This is in comparison to values of between 0.80 and 0.90 for a similarly-sized water tank tested at NBS $[7,8]$ 。

It is proposed that the ratio of the charge or discharge capacity to the theoretical storage capacity be denoted as the devices' performance factors ( $P F)$. Using such performance factors rather than the charge capacity $\left(C_{c}\right)$ and discharge capacity $\left(C_{d}\right)$ presently used in ASHRAE Standard 94-77 has several advantages:

1. The performance factor is a dimensionless number which is independent of the physical size of the unit.

2. Use of the performance factor tends to normalize the test results in more consistent values. Variation between tests of temperature and flow rate do not affect the value of the performance factors nearly as much as they do the charge and discharge capacities presently used $[7,8]$.

3. The performance factor relates the performance of the unit to the theoretical maximum performance of any completely sensibleheat storage device.

The discharge capacity test results were very scattered. Transient test results for a phase-change device are in general highly dependent on the initial temperature, the phase-change temperature, and the temperature step function. This effect can most readily be seen in the discharge tests where the difference between the input temperature and the phasechange temperature averaged only about $6^{\circ} \mathrm{C}\left(11^{\circ} \mathrm{F}\right)$. Referring to Table 2, it is evident that for the discharge tests, the closer the input temperature was to the phase-change temperature, $32^{\circ} \mathrm{C}\left(89^{\circ} \mathrm{F}\right)$, the smaller the discharge capacity. The tests at NBS were affected by doing the tests in a summer in a poorly-conditioned space which resulted in lack of control over the charge test initial temperature and discharge test input temperature. Strict requirements should be included in the Standard on the value of the temperatures to be used for phase-change units.

The discharge capacity averaged approximately $130 \mathrm{MJ}\left(1.2 \times 10^{5} \mathrm{Btu}\right)$ and the corresponding average value of the performance factor for the discharge tests was 0.33 .

The low values for discharge capacity obtained indicate a possible problem with this particular phase-change unit for space heating. During discharge, once the sensible heat above the transition temperature $\left(32{ }^{\circ} \mathrm{C}\right)$ has been extracted, the rate of energy extraction is 1 imited by the 


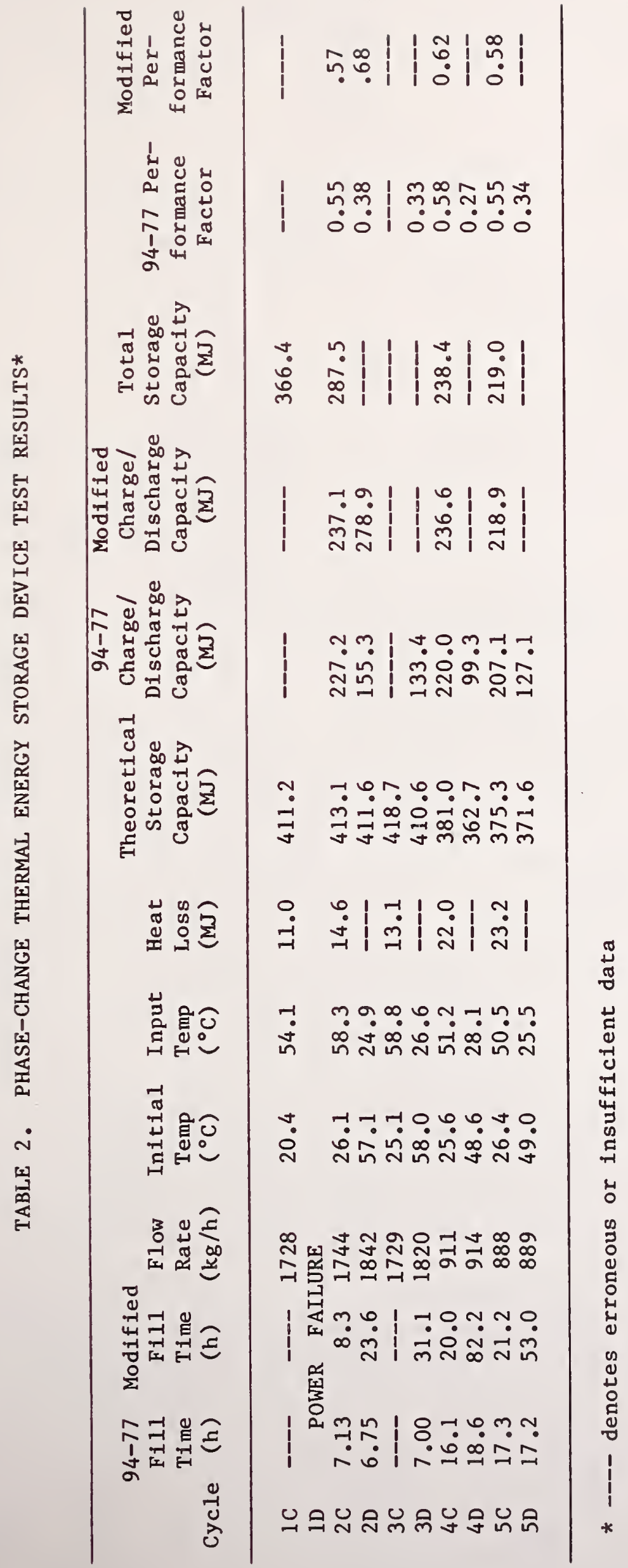


difference between the entering fluid temperature and the transition temperature. It may be difficult to heat a space with a source temperature of $32^{\circ} \mathrm{C}\left(89^{\circ} \mathrm{F}\right)$. It would be useful to designers if the test results from Standard $94-77$ tests included a plot of delivery heat rate as a function of time.

ASHRAE Standard 94-77 suggests a plot be provided showing the time variation in transfer fluid temperature for each test. Figure 9 shows such a plot for those tests involving the ASHRAE-recommended test fill times and temperature step changes. The abscissa represents time from $\tau=0$ to $\tau=\tau_{c, d}$ and the ordinate is a non-dimensional quantity:

$$
\frac{t_{\text {in }}-t_{\text {out }}}{\Delta t}
$$

In equation (8), the initial step change in transfer fluid inlet temperatures, $\Delta t$, is a constant. However, the difference between the transfer fluid outlet and inlet temperatures decreases with time yielding the curves of Figure 9. For a sensible-heat thermal energy storage device with perfect stratification and no heat loss to the ambient, the temperature of the inlet transfer fluid, $t_{i n}$, and the outlet transfer fluid, tout, would remain constant for the entire test fill time period (time for one entire volume change), at which time they would become equal. A curve of test results for such a device would be represented by a rectangle in Figure 9 。

The concept of using a non-dimensional plot showing the storage capabilities of thermal energy storage devices relative to those of an ideal device has been proposed [5]. Such a non-dimensional plot is shown in Figure 10 for ideal thermal energy storage units. The ordinate is the nondimensional quantity as before:

$$
\frac{t_{\text {in }}-t_{\text {out }}}{\Delta t}
$$

The abscissa represents a non-dimensional time defined by:

$$
\frac{w_{t f} c_{t f} \Delta t}{\operatorname{TSC}}
$$

where $\tau=$ time, $s$

An ideal, perfectly-insulated, completely-stratified, sensible-heat thermal storage device is represented by the dashed rectangle in Figure 10. A value of non-dimensional time equal to 1.0 corresponds to the time required to fully-charge such an ideal device (test fill time). The area under the curve for this ideal device is 1.0 .

If a perfectly-insulated, completely-mixed, sensible-heat thermal energy storage device was possible, the resulting curve would be the exponential solid curve in Figure 10. Again the total area under the curve out to an 


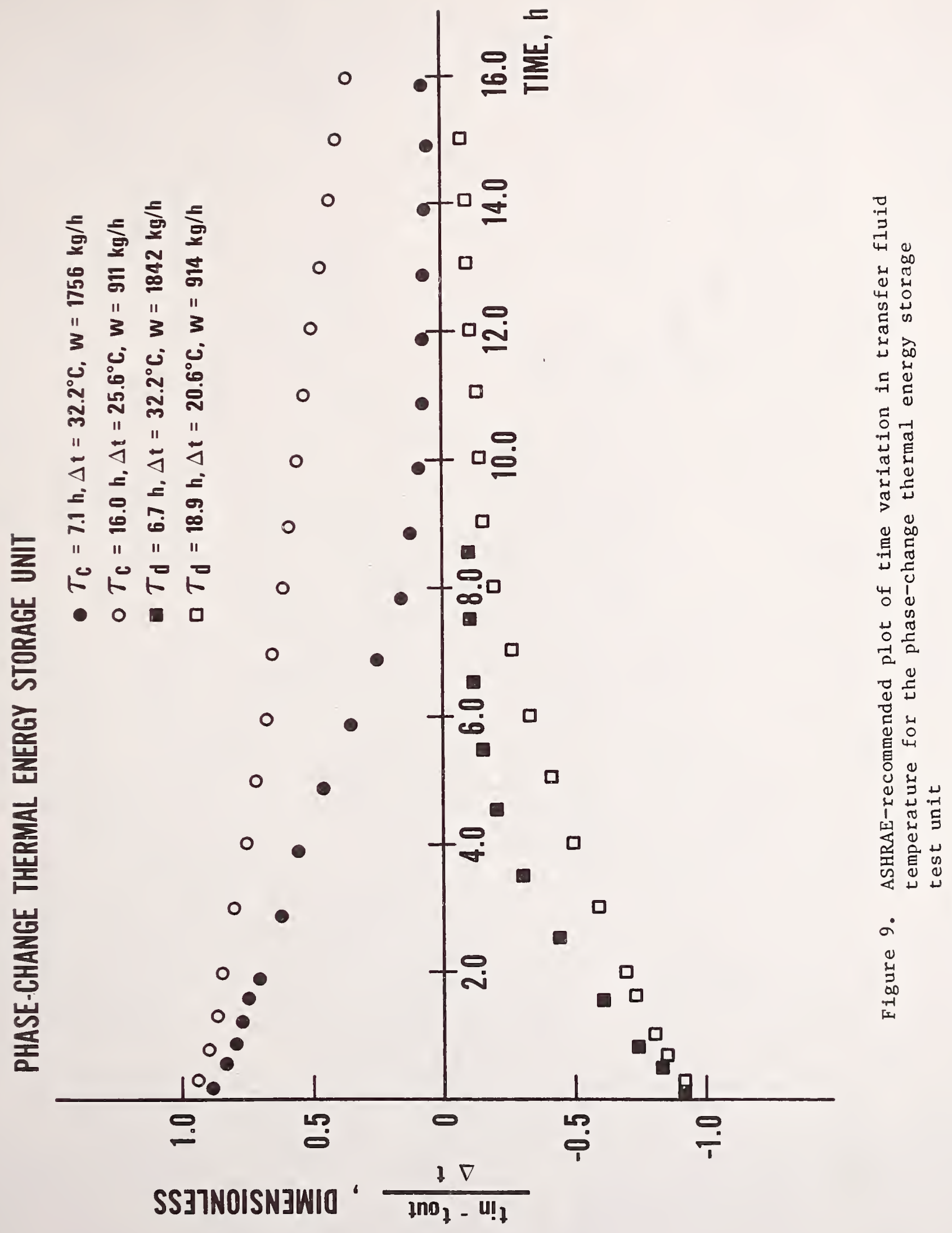




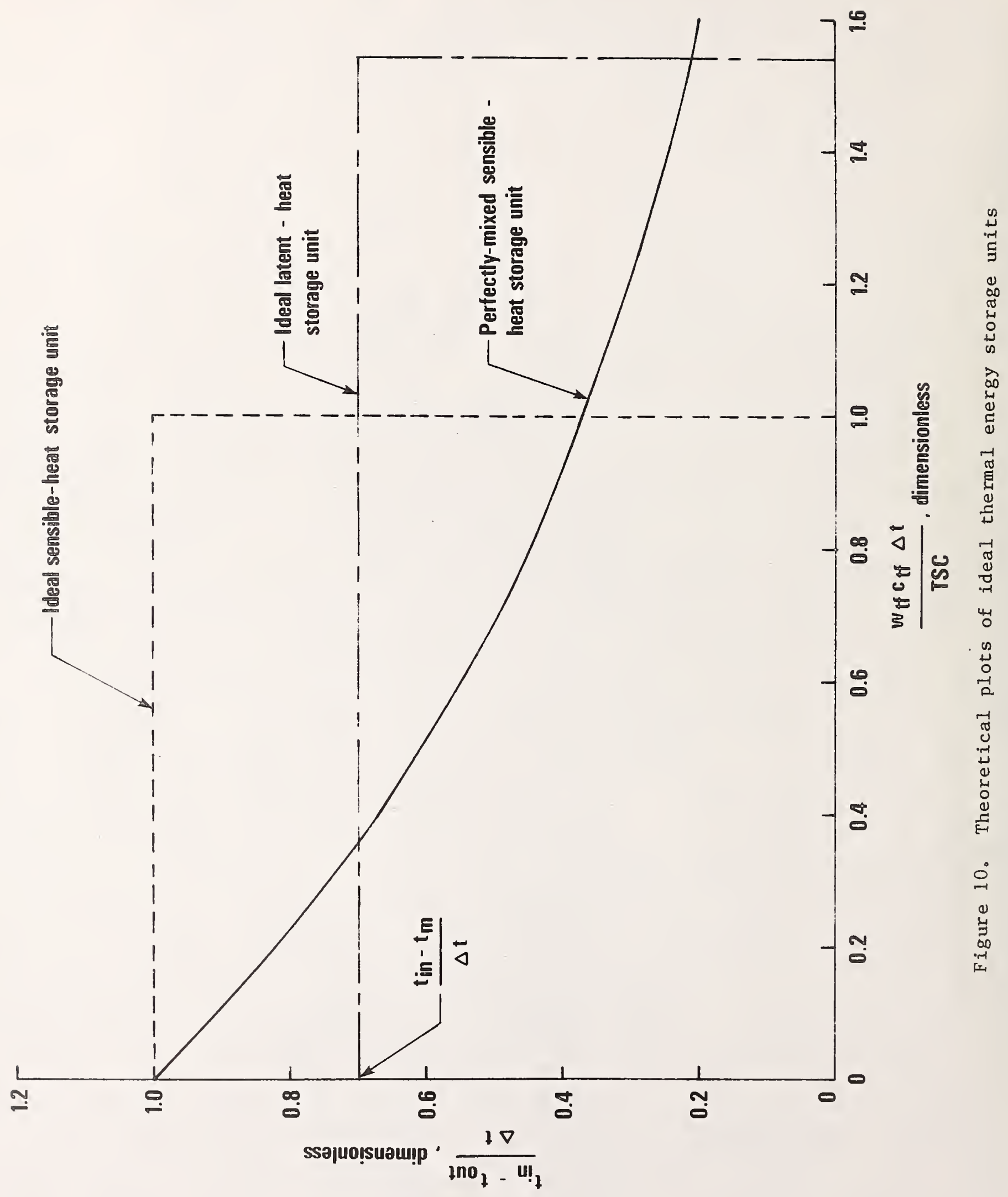


abscissa value of $\infty$ is 1.0 . However, if the area under the curve were calculated from dimensionless time of 0 to 1.0 , the value would be 0.632 , which corresponds to the ratio of energy stored by the ideal completelymixed sensible-heat device over the test fill time compared to the ideal stratified device. This is precisely the performance factor described above and as a result, such a dimensionless plot would be an ideal way to show graphically the meaning of the performance factor.

The foregoing analysis was based on the performance of sensible-heat thermal energy storage devices. Devices which use latent-heat for energy storage behave differently. A perfectly-insulated, completelystratified, ideal latent-heat device with a phase-change temperature, $t_{m}$, would behave as shown in Figure 10. Note that the ideal device would not be fully-charged at a dimensionless time of 1.0 . Also note that the area under the curve between a dimensionless time of 0 and 1.0 depends on the relative values of the phase-change, initial inlet, and step change in inlet temperature. Any latent-heat thermal energy storage device will also store some energy in the form of sensible heat. The curve for an ideal device with both latent and sensible-heat contributions is difficult to visualize; however, the fill time for such an ideal device can be calculated as explained below.

The theoretical storage capacity (TSC) of the combined latent-sensible device is:

$$
\mathrm{TSC}=\mathrm{MC}_{\mathrm{p}} \Delta \mathrm{t}+\mathrm{MH} \mathrm{H}_{\mathrm{L}}
$$

where $M=$ mass of storage material, $\mathrm{kg}$

$c_{\mathrm{p}}=$ sensible specific heat of the material, $\left.\mathrm{J} /\left(\mathrm{kg} \cdot{ }^{\circ} \mathrm{C}\right)\left(\mathrm{Btu} / \mathrm{lb} \cdot{ }^{\circ} \mathrm{F}\right)\right)$

${ }^{H_{L}}=$ latent heat of the material at the phase-change temperature, $\mathrm{t}_{\mathrm{m}}, \mathrm{J} / \mathrm{kg}(\mathrm{Btu} / \mathrm{Ib})$

The fill time components can be calculated from the following expression:

$$
\tau_{F, x}=\frac{T S C}{w_{t f} c_{t f} \Delta t_{x}}
$$

For the sensible-heat portion, $\Delta t_{x}$ is the difference between the inlet fluid temperature, $t_{i n}$, and initial storage temperature, $t_{i}$. For the latent-heat portion, $\Delta t_{x}$ is the difference between the inlet fluid temperature, $t_{i n}$, and the phase-change temperature, $t_{m} \cdot$ Consequently, for the combined latent-sensible device: 


$$
\begin{aligned}
& \tau_{F}=\frac{M c_{p}\left(t_{\text {in }}-t_{i}\right)}{w_{t f} c_{t f}\left(t_{i n}-t_{i}\right)}+\frac{M H_{L}}{w_{t f} c_{t f}\left(t_{i n}-t_{m}\right)} \\
& \text { or } \\
& \tau_{F}=\frac{M c_{p}\left(t_{i n}-t_{i}\right)+{ }^{M} \frac{\left(t_{i n}-t_{i}\right)}{\left(t_{i n}-t_{m}\right)}}{{ }_{t f} c_{t f}\left(t_{i n}-t_{i}\right)}
\end{aligned}
$$

Note that if the phase-change temperature were exactly half way between the initial temperature, $t_{i}$, and the input temperature, $t_{i n}$, equation (13) would reduce to:

$$
\tau_{F}=\frac{M c_{p}+2 M H_{L}}{{ }_{t f} c_{t f}}
$$

Also note that if the sensible-heat contribution were small and could be assumed to be zero:

$$
\tau_{F}=\frac{2 \mathrm{MH}_{\mathrm{L}}}{\mathrm{w}_{\mathrm{tf}} \mathrm{c}_{\mathrm{tf}}}
$$

In other words, the fill time would be exactly twice that called for in the present version of Standard 94-77.

It is recommended that the fill time for latent-heat storage devices be calculated using equation (12) or (13) (denoted hereafter in this report as modified fill time) instead of equation (3) as is presently required in Standard 94-77. In this way, latent-heat devices will be evaluated more equitably with sensible-heat devices.

The data from the transient tests on the phase-change device were reanalyzed using the modified fill time and the results are also shown in Table 2. The modified charge capacity (the charge capacity calculated using the modified fill time) was calculated to average $230 \mathrm{MJ}$ $\left(2.2 \times 10^{5} \mathrm{Btu}\right)$ compared to $220 \mathrm{MJ}\left(2.1 \times 10^{5} \mathrm{Btu}\right)$ using the fill time of equation ( 3 ). The performance factor for the charge tests averaged 0.59 (compared to 0.56). Because the input temperature was so close to the phase-change temperature during the discharge tests, the modified fill time for most of the tests was on the order of several days. The tests were not run that long and as a result, the discharge capacities and corresponding performance factors could not be calculated using the modifed fill times.

The test results for the transient tests were plotted in accordance with the completely dimensionless plot described above. Figure 11 is such a plot for charge tests at two flow rates using the Standard 94-77 fill time. A second plot using the modified fill time is shown in Figure 12. A plot of the inlet and outlet transfer fluid temperatures as a function of time is shown in Figure 13 for the charge test where $\tau_{c}=7.2 \mathrm{~h}$. It 


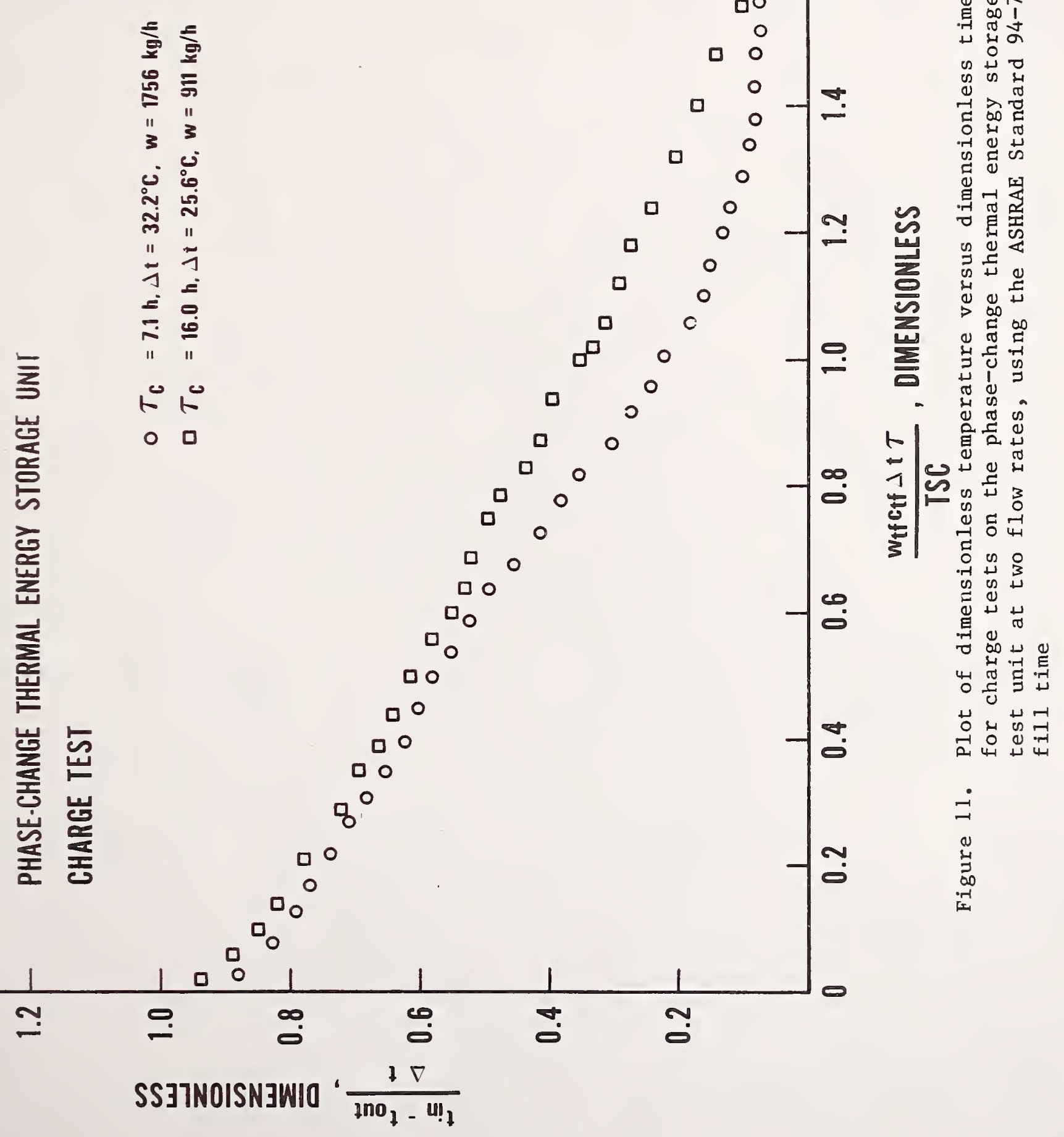




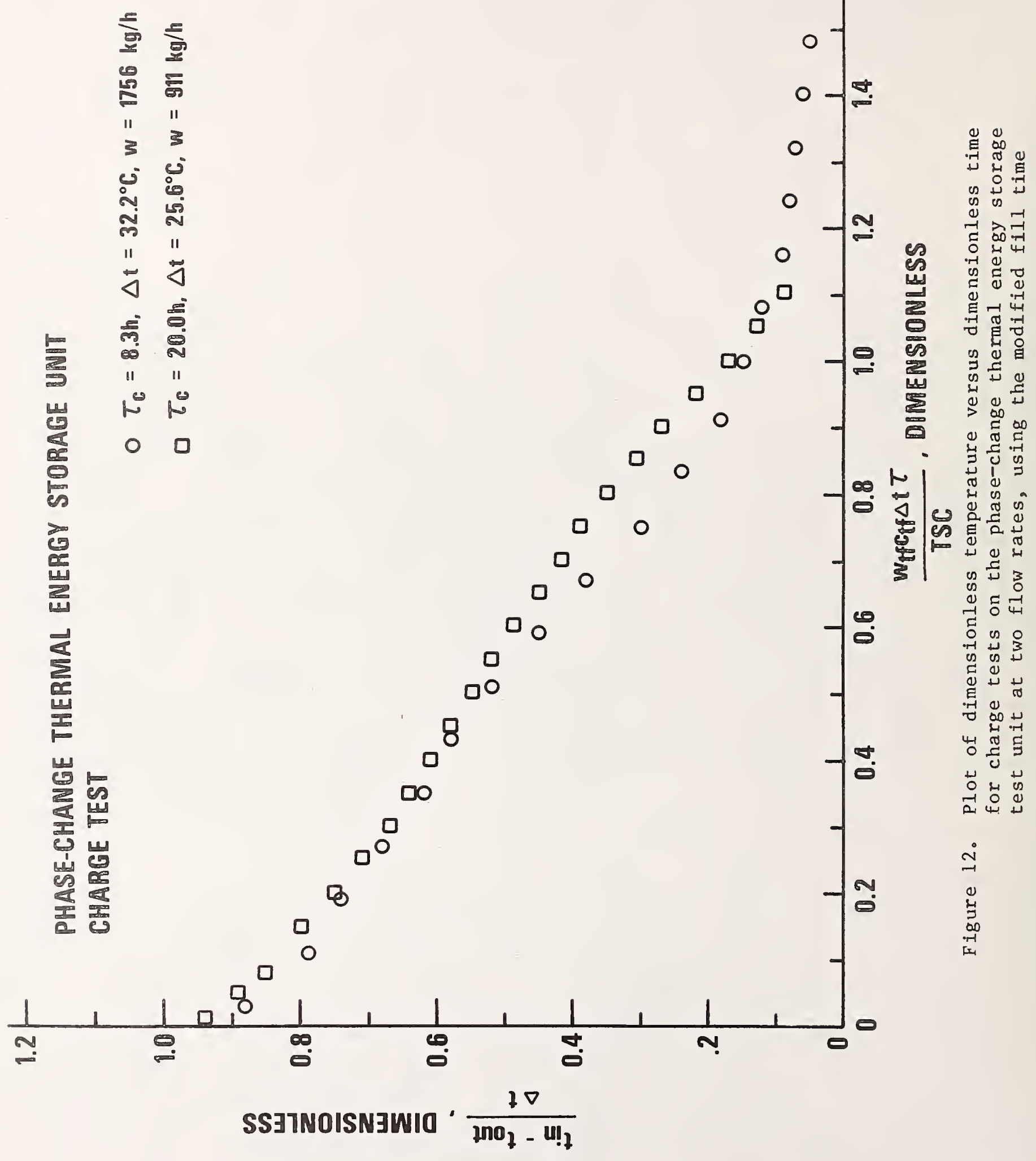




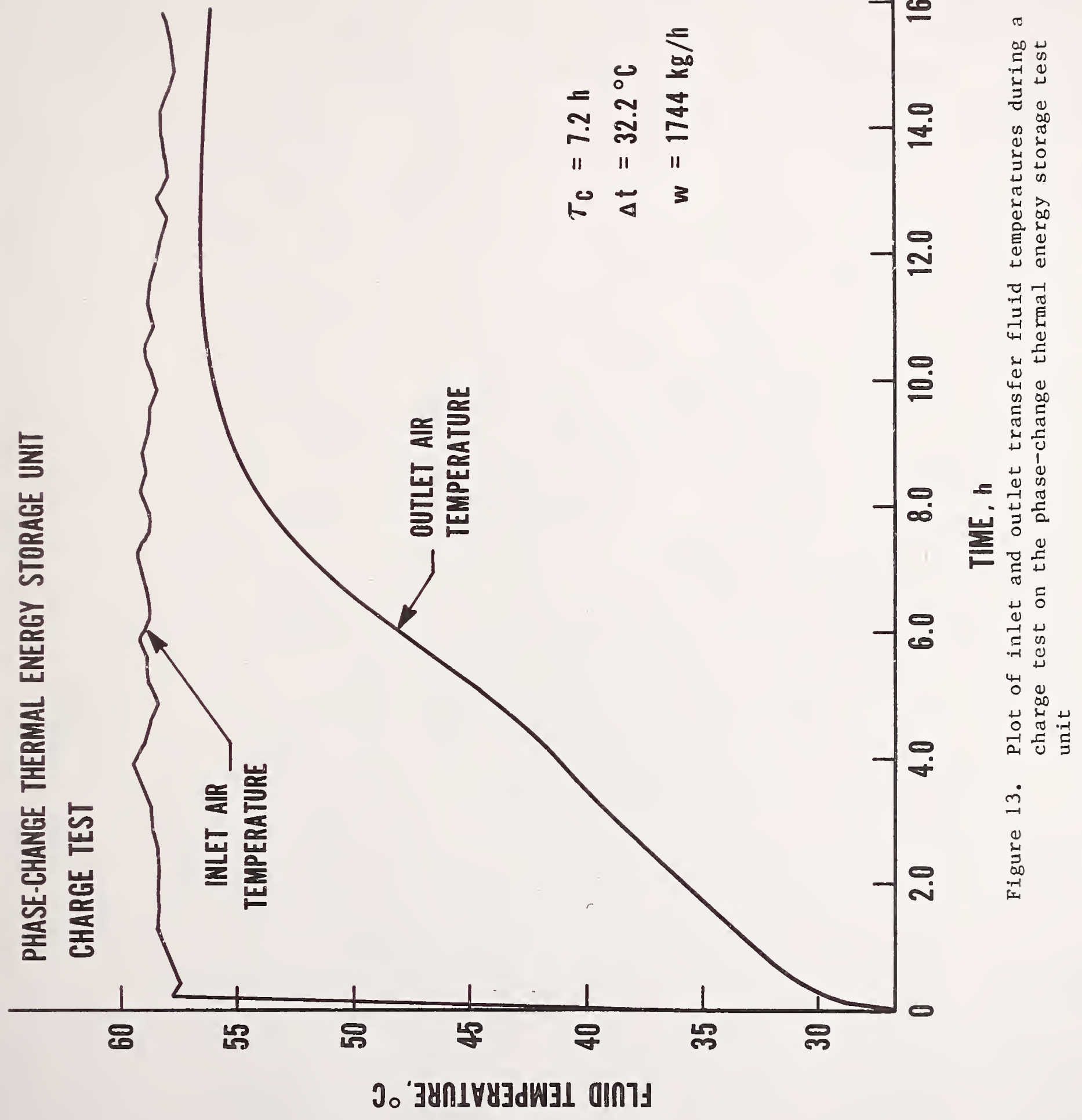


distinctly shows the temperature step increase in the inlet transfer fluid and the outlet fluid temperature variation with time.

\section{Internal Behavior}

The thermocouples placed in the airstream and pressed into stacking slots yielded temperature readings which agreed very closely at each tray location. This indicates a high heat transfer rate from the fluid to the tray. The thermocouples in the stacking slot were not immersed in the phase-change material (PCM). Figure 14 is a plot of air temperatures at seven tray locations along the flow path length. The plot shows a high degree of stratification in temperature in the direction of flow. In the length of $0.3 \mathrm{~m}$ ( $1 \mathrm{ft}$ ), the temperature changed as much as $8{ }^{\circ} \mathrm{C}$ $\left(15^{\circ} \mathrm{F}\right)$ along the same flow channel. The fluid exit temperatures, however, were not consistent with the stratification observed in the trays as can be seen in Figure 14. This leads one to conclude that a significant portion of the flow was somehow by-passing the trays. It is possiible that a large part of the flow passed down the spaces between the top trays and the tops of the eight plywood cells where there were no tray support legs to restrict flow. Fourteen thermocouples in the other seven flow cells all exhibited the same temperature for the corresponding location in the flow cell shown in Figure 14, indicating no flow imbalance between the eight flow cells.

\section{Thermal Performance Degradation}

One possible problem area with phase-change devices is the degradation of performance due to either separation of phase-change material or super-cooling due to lack of nucleation sites. Hence, 30 cycle preconditioning is required by Standard 94-77 prior to performing the performance tests. As mentioned previously, the approach used in these tests was to use no pre-conditioning. The degradation that did occur over the five cycles can be seen however for the charge test results in Table 2 .

The degradation of the unit can be checked in two ways: (1) by observing the changes in the charge and discharge capacities determined in accordance with the Standard, or (2) by observing the changes in the estimated total thermal capacity of the unit which was also determined experimentally from the measurements made and is given in Table 2.

Problems were experienced during test cycles (1) and (3) with the proportional temperature controller used to control the inlet temperature to the device so that the charge and discharge capacities indicated from these tests are not valid. Test cycles (4) and (5) produced similar results for charge capacities.

The second technique of estimating the total thermal energy storage capacity of the unit after each cycle was done by charging the unit much longer than the test fill time and until the exit temperature was constant. The measured amount of energy charged into the device less an allowance for heat loss was then assumed equal to the total thermal capacity. An unsteady inlet temperature (which occurred during cycles 


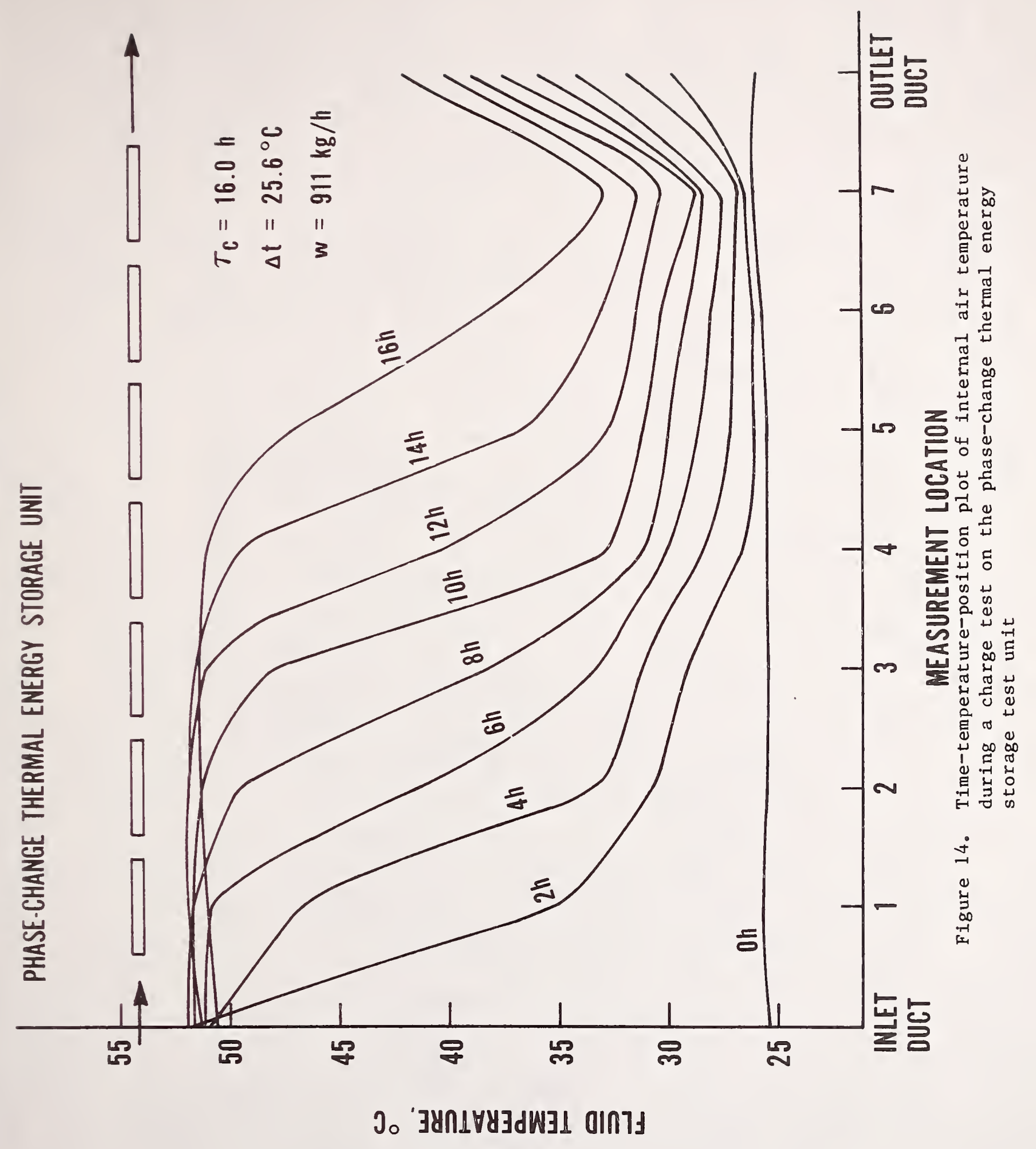


(1) and (3)) did not affect the results since a numerical integration of the difference in temperature between inlet and exit (see equation (6)) was done. On the first charge test, the total thermal capacity of the unit was calculated to be $90 \%$ of the theoretical capacity. On cycle (2), the total capacity dropped to $70 \%$. On cycles (4) and (5), the capacity was approximate $1 y$ $60 \%$ of the theoretical capacity.

\section{PEBBLE-BED TEST RESULTS}

Pebble-bed tests were completed at the NBS test facility in August and September, 1978. Seven complete charge - heat loss - discharge test cycles were run, four at the flow rate recommended by the manufacturer and three at one-half the recommended flow rate. Air stream pressure drop at the recommended flow rate was $0.068 \mathrm{kPa}\left(0.27\right.$ in. $\left.\mathrm{H}_{2} 0\right)$.

Heat Loss Test

A heat loss test was included in all seven test cycles and resulted in an overal1 heat loss coefficient of $95 \mathrm{~kJ} /\left(\mathrm{h} \cdot{ }^{\circ} \mathrm{C}\right)\left(50 \mathrm{Btu} / \mathrm{h}{ }^{\circ} \mathrm{F}\right)$ for both flow rates. An estimation of the heat loss factor utilizing basic heat transfer theory, the material properties and dimensions of the pebblebed containers, and assuming no air leakage, yielded an approximate overal1 heat loss coefficient of $\left.36 \mathrm{~kJ} /\left(\mathrm{h}^{\circ}{ }^{\circ} \mathrm{C}\right)\left(19 \mathrm{Btu} / \mathrm{h}^{\circ}{ }^{\circ} \mathrm{F}\right)\right)$. Heat 1 oss during the transient tests generally was on the order of 3 to 8 percent of the energy transferred during a test fill time period.

\section{Charge and Discharge Tests}

The results for the charge and discharge tests for all seven test cycles of the pebble-bed are shown in Table 3 . The charge capacity determined ranged from 258 to $320 \mathrm{MJ}\left(2.44 \times 10^{5}\right.$ to $\left.3.03 \times 10^{5} \mathrm{Btu}\right)$ and the discharge capacity from 247 to $293 \mathrm{MJ}\left(2.34 \times 10^{5}\right.$ to $2.78 \times 10^{5}$ Btu). Charge and discharge capacities are highly dependent on test temperatures as has been indicated previously.

The performance factors for the charge tests as defined in the previous Section ranged from 0.79 to 0.87 and from 0.80 to 0.86 for the discharge tests。 In general, the performance factor for the charge tests was higher at higher flow rates due to less heat loss over the shorter fill time. Moisture exchange with the air stream was not taken into account in the calculation of charge or discharge capacity.

A plot of charge and discharge test results at both flow rates as required by the standard is shown in Figure 15.

The non-dimensional plot of the same two charge tests as on Figure 15 is shown in Figure 16. Note that the results for the two different flow rates fall nearly on the same curve, indicating that the thermal performance of the pebble-bed is not greatly affected by flow rate. Similar plots of all charge tests followed the same curve. 


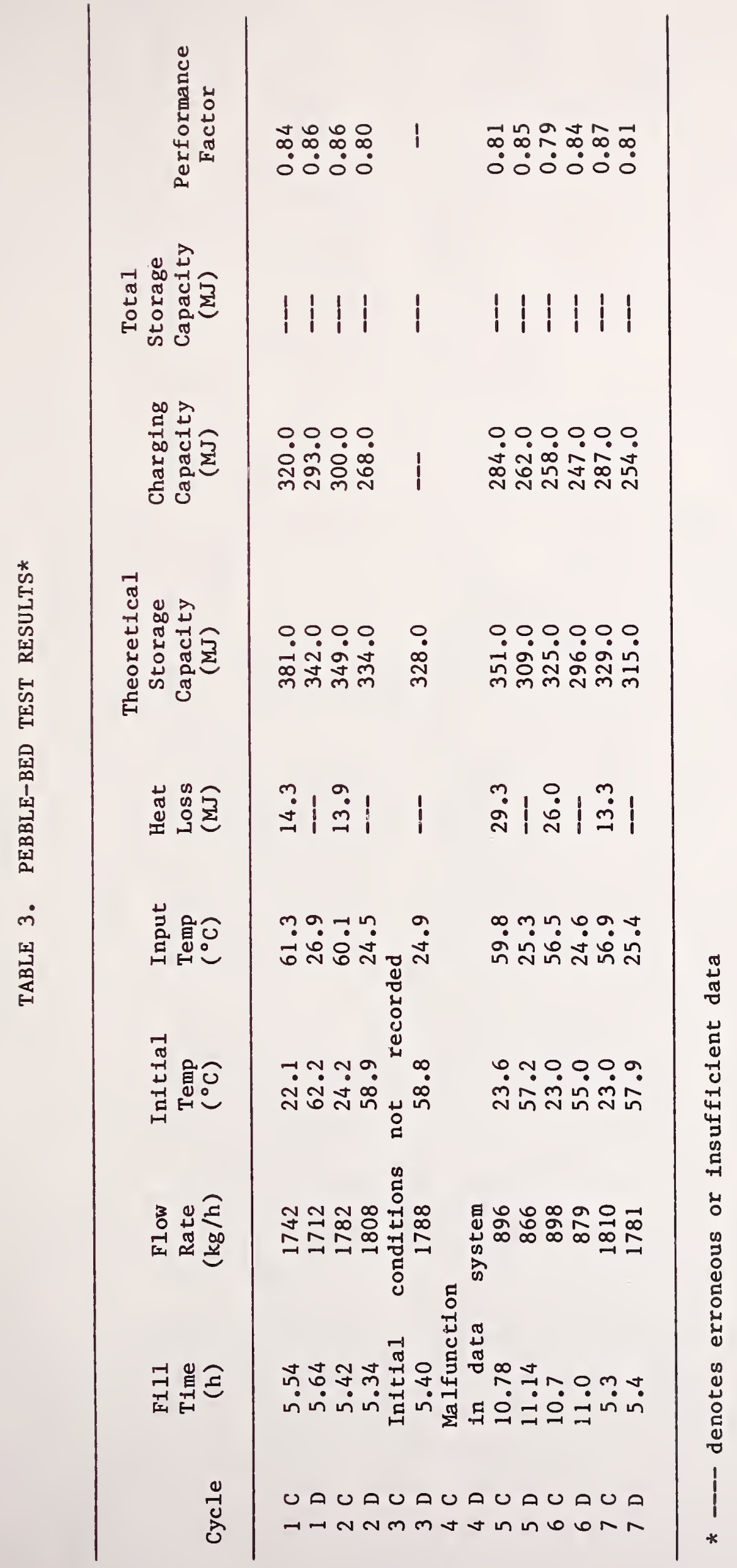




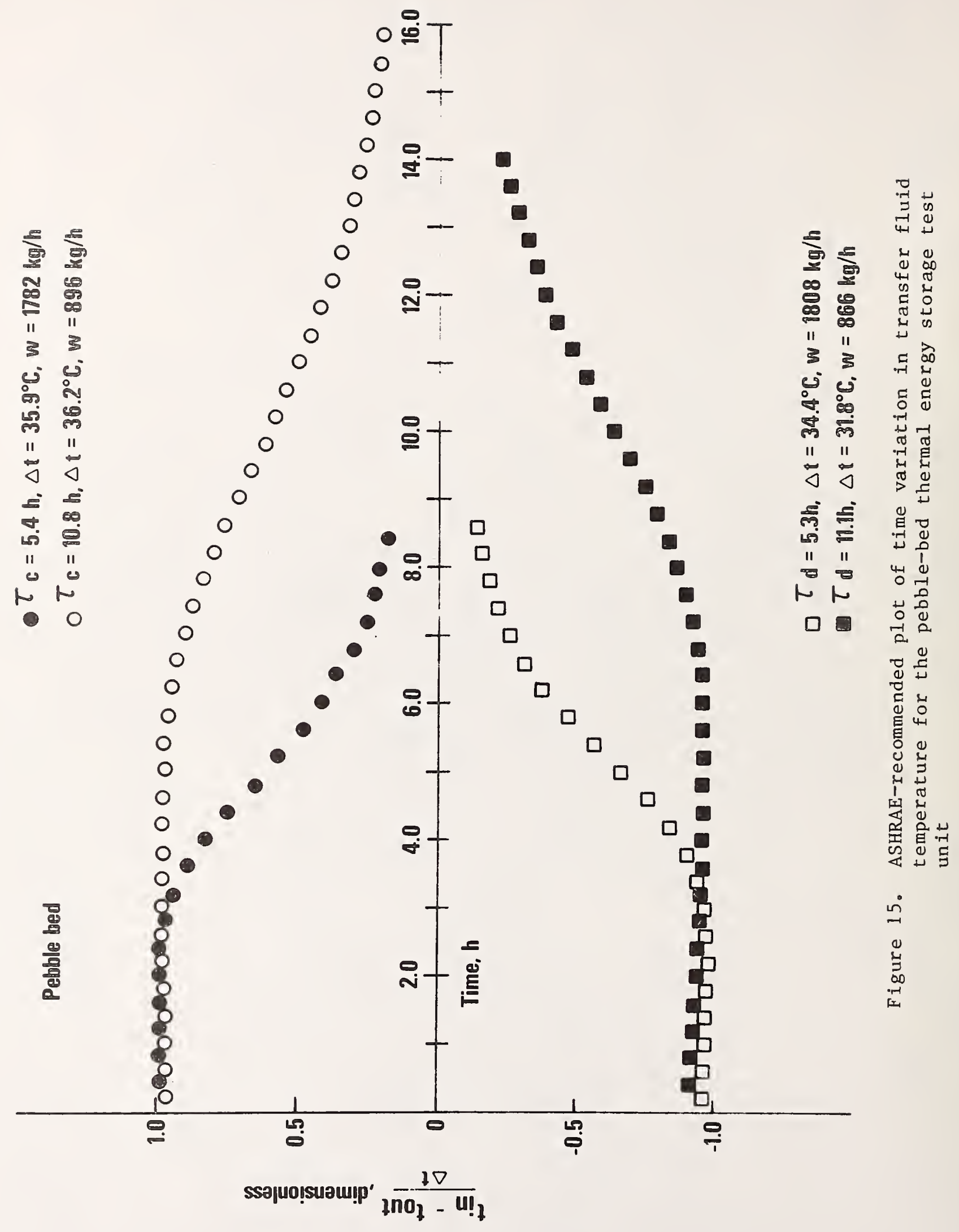




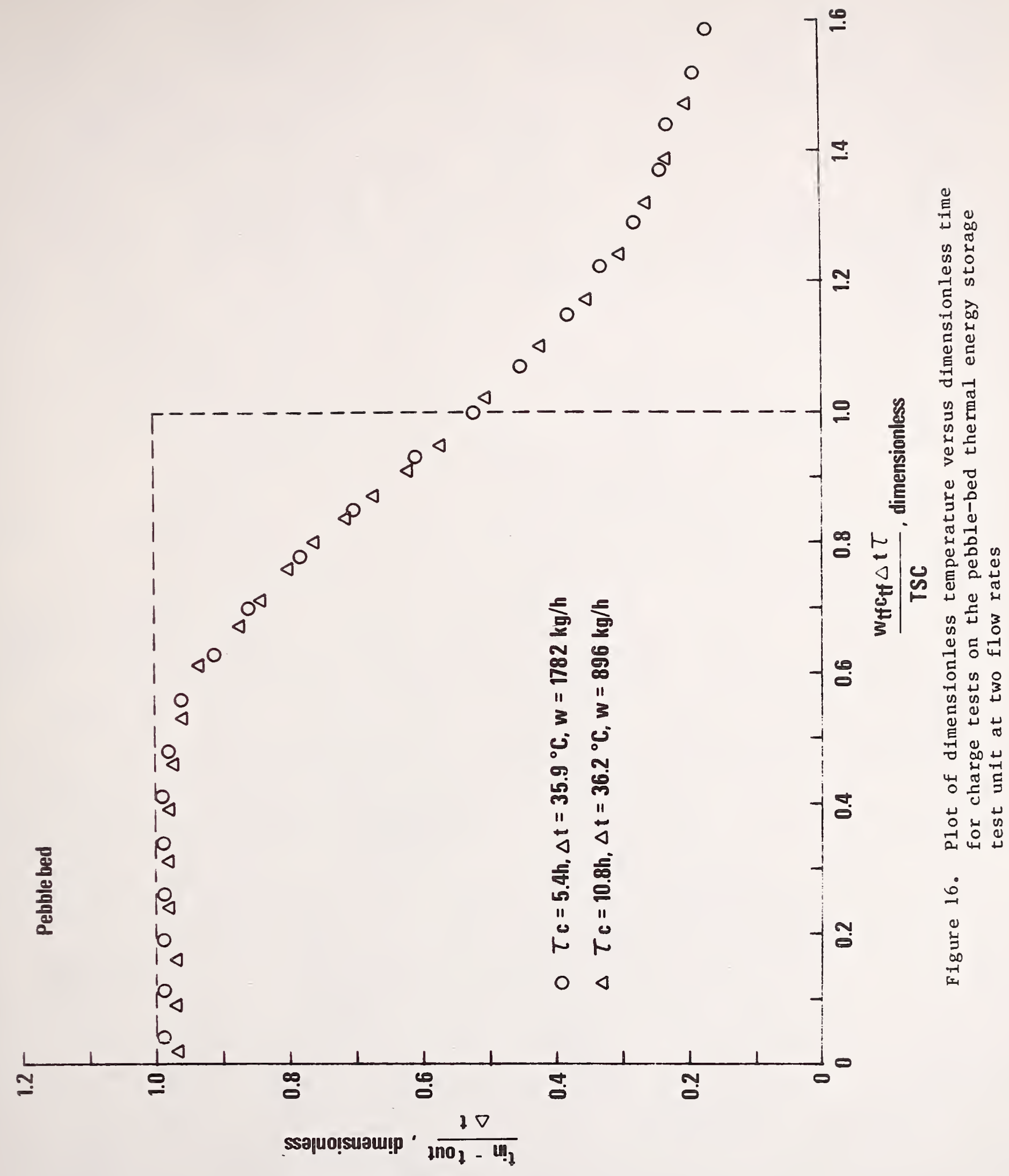


The thirteen thermocouples spaced evenly along the flow path within the pebble-bed were used to produce the plot in Figure 17 for a typical charge test. The pebble-bed showed a large degree of stratification as evidenced by the shape of the curve in the first hours of the test. Exiting bed temperatures did not vary significantly from the exiting duct temperatures throughout the tests indicating that the flow was uniform across the cross-section of the pebble-bed.

\section{Moisture Exchange Effects}

Pebble-beds are known to exchange moisture with the air stream which has a significant effect on the performance of the bed [14,15]. Attempts were made during the tests to quantify this process, but problems with the measurement and control of air stream humidity as previously indicated prevented any quantitative analysis.

In general, moisture is released from the pebble bed during charging and absorbed during discharging $[14,15]$. The mechanism of moisture exchange is a sorption process in which moisture is exchanged between the air and the fine pores of an absorbent. During the process, there is an energy exchange equal to the latent heat of vaporization of the water. The quantity of water finally held by a given sorbent when equilibrium has been reached is dependent only on the relative humidity of the contacting air-water vapor mixture [13]. This ratio is largely independent of the temperature of operation and of the vapor pressure at which the water exists in the air mixture。

Although the exchange of moisture in the rock bed was not well characterized by these tests, the bed should behave in general as follows:

1. Initially the bed will be at thermal and moisture equilibrium with the cool pre-charging air stream assuming entering temperature and humidity are held constant.

2. Charging, which is accomplished with air of high temperature and low relative humidity, will raise the temperature of the rocks and extract moisture from them. Energy is stored in both the sensible temperature increase of the rocks and in the "dryness" of the bed.

3. Discharging, which is accomplished with air of low temperature and high relative humidity, will lower the temperature of the rocks and deposit moisture in them. Energy removed from the bed is contributed by the sensible heat of the rocks and the heat of vaporization as the water changes from vapor to liquid.

As an illustration of the storage of heat through "dryness", imagine an ideal massless desiccant which is at an equilibrium condition of $21^{\circ} \mathrm{C}$ $\left(70^{\circ} \mathrm{F}\right.$ ) and $10 \%$ relative humidity. If air at $21^{\circ} \mathrm{C}\left(70^{\circ} \mathrm{F}\right)$ and $50 \% \mathrm{RH}$ with a corresponding enthalpy of $58.7 \mathrm{~kJ} / \mathrm{kg}(25.2 \mathrm{Btu} / 1 \mathrm{~b})$ is introduced into 


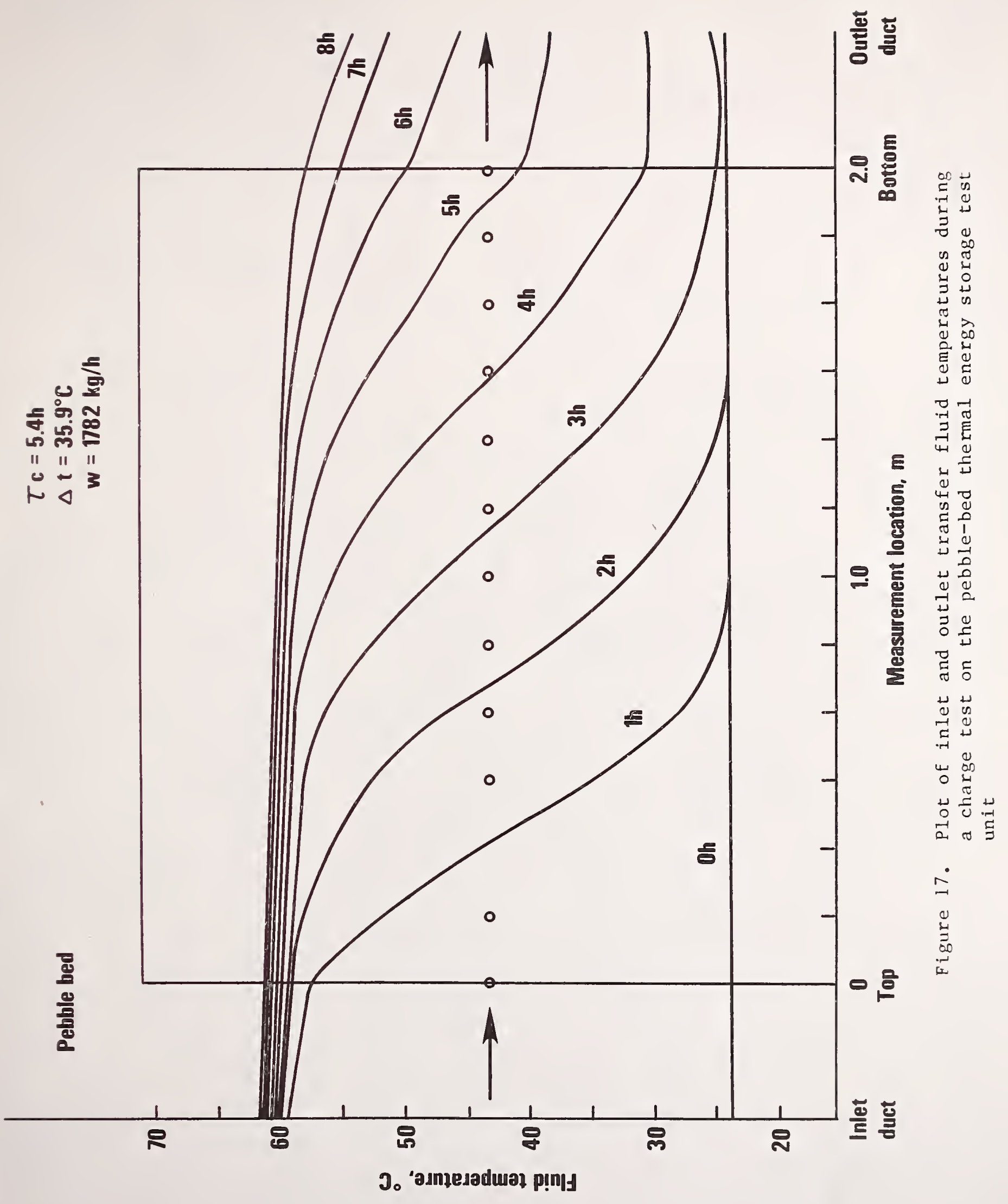


the unit, the desiccant absorbs $0.0023 \mathrm{~kg}(0.005 \mathrm{lb})$ of water per $\mathrm{kg}(1 \mathrm{~b})$ of air in bringing the air from $50 \% \mathrm{RH}$ to the $10 \% \mathrm{RH}$ equilibrium condition. A total of $12.3 \mathrm{~kJ} / \mathrm{kg}(5.3 \mathrm{Btu} / \mathrm{lb})$ of heat will be released from the condensed water. Air exiting from this massless unit will then have an enthalpy of $71.1 \mathrm{~kJ} / \mathrm{kg}(30.5 \mathrm{Btu} / 1 \mathrm{~b})$ and a temperature of $40^{\circ} \mathrm{C}$ $\left(104^{\circ} \mathrm{F}\right)$ 。

The above example illustrates the large effect moisture transfer could have on thermal energy storage capacity. In fact, use of desiccants as thermal energy storage media has been suggested [14,15]. A desiccant thermal energy storage device would have the advantage of a high energy density at relatively low temperatures.

It is apparent from analysis of the phenomena of moisture exchange with porous beds that the present $S$ tandard should include requirements to cover this situation. Inlet humidity conditions for tests must be established in order to rate various thermal energy storage devices equitably。

In Section 8.2 of the Standard it is suggested that an energy balance approach be used for rating a thermal energy storage device when there is a net moisture exchange between the air stream and the device. In contrast, Close suggests a rating based on sensible heat exchange only when the thermal energy storage device is used for heating purposes [14]。 Close 's recommendation seems to be the most feasible for pebble-beds since the moisture exhange process is one that will occur in a random fashion and primarily based on the system design and geographical location of the system。

In order for the moisture exchange process to be controlled properly in the test, Standard 94-77 requires modification. Section 8.2 states that the inlet and exit dew-point temperatures shall be equal and remain constant which will be impossible for some devices. Three alternate approaches for establishing the inlet humidity conditions are:

1. Use a closed test loop and a drier to remove all significant quantities of moisture from the air and the bed prior to starting the test.

2. Use a closed test 1oop, but initially have the bed at equilibrium at a specified condition prior to a transient test. This approach would simulate a closed loop with a solar collector such as exists in a solar heating system.

3. Use an open test loop with the inlet humidity conditions controlled to a specified condition.

\section{CONCLUSIONS AND RECOMMENDATIONS}

A total of five tests on a phase-change thermal energy storage unit and seven tests on a pebble-bed were completed in accordance with ASHRAE Standard 94-77. It was found that the heat loss characteristics and the amount of energy charged into or discharged from the device could be 
quantified through the use of the Standard. However, based on this study, the following recommendations are made:

1. Flow rate requirements in ASHRAE Standard 94-77 for thermal energy storage devices utilizing air as the transfer fluid should be changed to reflect flow rates normally seen in installed solar systems. The flow rate is currently specified in terms of the test fill time. This may have to be changed if recommendation 3 , below is adopted.

2. The temperature difference for the heat loss test should be changed from $25^{\circ} \mathrm{C}$ to $35^{\circ} \mathrm{C}$ so that the heat loss test can be conducted conveniently in conjunction with the transient charge and discharge tests.

3. For thermal energy storage devices in which energy storage capacity is temperature dependent (i.e. a phase-change device), the relationship between the phase-change temperature, initial temperature, and input temperature should be specified so that the devices can be consistently tested and rated.

4. For phase-change thermal energy storage devices, the fill time used in the computation of the charge and discharge capacity should be calculated using equation (13) or (14) in this report.

5. For latent-heat energy storage devices, delivery heat rate and fluid exit temperature should be included in the test results required to be reported by the Standard.

6. Thermal energy storage devices which exchange moisture with the air flow stream (e.g. a pebble-bed) should be tested using specified inlet air conditions.

7. The charge and discharge capacities of a pebble-bed should be based on sensible heat exchange only.

8. The dimensionless plots described in this report should be used in the analysis of test results. The utilization of such plots should provide a suitable means for comparing thermal performance of different thermal energy storage devices.

9. The performance factor described in this report provides a relative rating factor independent of the size of the unit and should be used in rating thermal energy storage devices.

10. Even though the test results should allow a relative ranking of different thermal energy storage devices, the relationship between test results and real-world system performance needs to be established for typical devices. 
1. Hill, J.E., and T. Kusuda, "Method of Testing for Rating Solar Collectors Based on Thermal Performance," NBS Report NBSIR 74-635, December, 1974 。

2. Kelly, G.E., and J.E. Hill, "Method of Testing for Rating Thermal Storage Devices Based on Thermal Performance," NBS Report NBSIR 74-634, Apri1, 1975.

3. Hill, J.E., Streed, E.R., Kelly, G.E., Geist, J.C., and T.Kusuda, "Development of Proposed Standards for Testing Solar Collectors and Thermal Storage Devices," NBS Technical Note 899, February, 1976.

4. Hill, JoE., and E.R. Streed, "A Method of Testing for Rating Solar Collectors Based on Thermal Performance," Solar Energy, Vol. 18, pp 421-429, 1976 。

5. Hill, J.E., Kelly, G.E., and B.A. Peavy, "A Method of Testing for Rating Thermal Storage Devices Based on Thermal Performance," Solar Energy, Vol. 19, pp. 721-732, 1977.

6. ASHRAE Standard 94-77--Methods of Testing Thermal Storage Devices Based on Thermal Performance, ASHRAE, 345 E. 47 th St., N.Y., N.Y。 $10017,1977$.

7. Hunt, B.J., Richtmyer, T.E., and J.E. Hill, "An Evaluation of ASHRAE Standard 94-77 for Testing Water Tanks for Thermal Storage", NBS Report NBSIR 78-1548, November, 1978.

8. Hunt, B.J., Richtmyer, T.E., and J.E. Hill, "Testing of Water Tanks for Thermal Storage According to ASHRAE Standard 94-77," ASHRAE Transactions, Vol。85, Part I, 1979.

9. ASHRAE Standard 93-77--Methods of Testing to Determine the Thermal Performance of Solar Collectors, ASHRAE, 345 E. 47 th St., N.Y., N.Y. 10017,1977 .

10. Hill, J.E., Jenkins, J.P., and D.E. Jones, "Testing of Solar Collectors According to ASHRAE Standard 93-77," ASHRAE Transactions, Vol. 84, Part II, 1978.

11. Hill, J.E., Jenkins, J.P., and D.E. Jones, "Experimental Verification of a Test Procedure for Solar Collectors," NBS Building Science Series 117, December, 1978.

12. ASHRAE Standard 41.1-74 Standard Measurements Guide: Section on Temperature Measurements, ASHRAE, 345 E. 47th St., N.Y., N.Y. 10017 , 1974 。

13. ASHRAE Handbook of Fundamentals, ASHRAE, 345 E. 47th St., N.Y., N.Y . 10017, 1977 . 
14. Close, D.J., and T.L. Pryor, "The Behavior of Absorbent Energy Storage Beds," Solar Energy, Vo1. 18, pp. 287-292, 1976.

15. Close, D.J., and R. V. Dunkle, "Use of Adsorbent Beds for Energy Storage in Drying of Heating Systems," Solar Energy, Vol. 19, pp. 233-238, 1977 . 


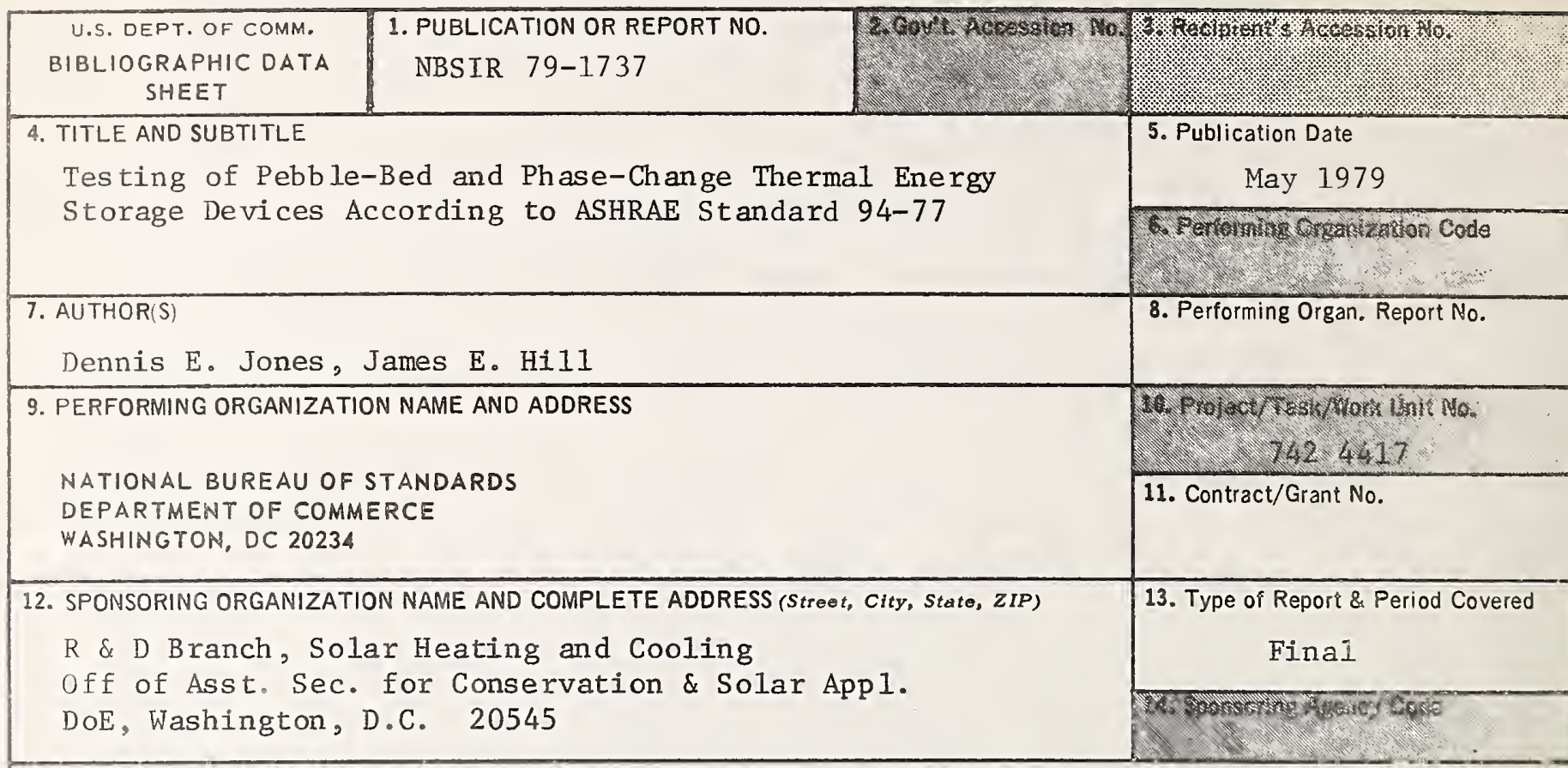

15. SUPPLEMENTARY NOTES

Document describes a computer program; SF-185, FIPS Sottware Summary, is attached.

16. ABSTRACT (A 200-word or less factual summary of most significant information. If document includes a significant bibliography or ijterature survey, mention it here.)

The American Society of Heating, Refrigerating, and Air Conditioning Engineers (ASHRAE) has recently adopted ASHRAE Standard 94-77 - Methods of Testing Thermal Storage Devices Based on Thermal Performance. Experiments have been completed at the National Bureau of Standards in which a $7 \mathrm{~m}^{3}$ (250 $\mathrm{ft}^{3}$ ) pebble-bed and a similarly-sized $264 \mathrm{MJ}(250,000 \mathrm{Btu})$ phase-change unit utilizing sodium sulfate decahydrate, both using air as the transfer fluid, were tested in accordance with this Standard. A description of the test procedure, test apparatus, and detailed test results is given. Some problems were encountered in using the Standard for these kinds of thermal energy storage devices, and modifications to the Standard are recommended based on these experiments.

17. KEY WORDS (six to twelve entries; alphabetical order; capitalize only the first letter of the first key word unless a proper name; separated by semicolons)

ASHRAE Standard 94-77; Glauber's salt; latent heat storage; pebble bed; phasechange unit; solar energy storage; thermal energy storage device.
18. AVAILABILITY

$$
\text { [X] Unlimited }
$$

For Official Distribution. Do Not Release to NTIS

Order From Sup. of Doc., U.S. Government Printing Office, Washington, DC 20402, SD Stock No. SNÓ03-003-

X Order From National Technical Information Service (NTIS), Springfield, VA. 22161

\begin{tabular}{|l|c|}
\hline $\begin{array}{l}\text { 19. SECURITY CLASS } \\
\text { (THIS REPORT) }\end{array}$ & $\begin{array}{c}\text { 21. NO. OF } \\
\text { PRINTED PAGES } \\
\text { UNCLASSIFIED }\end{array}$ \\
\hline $\begin{array}{l}\text { 20. SECURITY CLASS } \\
\text { (THIS PAGE) }\end{array}$ & $\begin{array}{l}\text { 22. Price } \\
\text { UNCLASSIFIED }\end{array}$ \\
$\$ 4.50$ \\
\hline
\end{tabular}



